Universidade de São Paulo

ESCOLA SUPERIOR DE AGRICULTURA "LUIZ DE QUEIROZ"

\title{
EFEITOS DO GESSO COMO FONTE DE CÁLCIO E DE ENXOFRE NA CULTURA DA CANA-DE-AÇÚCAR \\ (Saccharum officinarum L.)
}

\section{FRANCISCO ALFREDO FERNANDES}

Orientador: FRANCISCO DE ASSIS FERRAZ DE MELLO

Dissertação apresentada à Escola Superior de Agricultura "Luiz de Queiroz", da Universidade de São Paulo, para obtenção do título de Mestre em Agronomia. Área de Concentração: Solos e Nutrição de Plantas.

PIRACICABA

Estado de São Paulo - Brasil

Novembro - 1985 
.ee.

A

meus

pais

FRANCI SCO

e

NAIR

OFERECO

A

minha

filha

TAT IANA

DEDICO 


\section{AGRADECIMENTOS}

- Ao Dr. Francisco de Assis Ferraz de MeZZo, pela amizade e orientação;

$\div$ Ao Dr. Eurípedes Malavolta, pelo apoio, sugestões e amizade;

- Ao Engo Agro AZfredo José Fernandes, pelo estímulo e incenti vo, além do valioso auxílio prestado;

- Ao Engo Agro Sergio Ricardo Celzoni, por seu desvelo e ajuda inestimável na parte de campo;

- Ao Sr. Alfredo José Ferraz de MeZzo, pela sua boa vontade e esmero nos serviços de datilografia;

- A Coordenação do Aperfeigoamento de Pessoal de Niver Supe rior (CAPES);

- Á Diretoria da Escola Superior de Agronomia de Paraguacu Pau Zista (ESAPP);

- A todos que, direta ou indiretamente, embora não citados, co boraram para o desenvolvimento desta obra;

- E a DEUS, cuja presença invisível se fez sentir em todos os momentos cruciais, ao longo do "infindável" número de horas que dediquei a este trabalho. 


\section{BIOGRAFIA DO AUTOR}

FRANCISCO ALFREDO FERNANDES, filho de Francisco. José Fernandes Junior e Nair Aissa Fernandes, nascido na cidade de São Paulo, Brasil, aos 3 dias do mês de novembro de 1947 .

Em 1977, obteve o diploma de Engenheiro Agrônomo pé Escola Superior de Agricultura "Luiz de Queiroz" da Universida de de São Paulo, na cidade de Piracicaba, Estado de São Paulo, Brasil.

Desde então, vem exercendo atividades de docência no ensino superior em Agronomia, sendo atualmente, docente da ca deira de Solos na Escola Superior de Agronomia de Paraguagu Pauiista, na cidade de Paraguaçu Paulista, Estado de São Pau 10, Brasil. 
1. INTRODUÇÃO E OBJETIVOS. . . . . . . . . . . . . . 1

2. REVISÃO DE LITERATURA . . . . . . . . . . . . 6

3. MATERIAL E METOdOS. . . . . . . . . . . 18

3.1. Local. . . . . . . . . . . . 18

3.2. Solo................. . . 18

3.3. clima. . . . . . . . . . . 2 2

3.4. Variedades estudadas. . . . . . . . 22

3.5. Desenho experimental. . . . . . . . . 25

3.6. Preparo do solo e demarcação do experimento. . 30

3.7. Plantio. . . . . . . . . . . 31

3.8. Adubação. . . . . . . . . . . 32

3.8.1. Aplicação dos tratamentos..... 32

3.8.2. Preparo dos materiais aplicados. . . 33

3.9. Diagnose foliar. . . . . . . . . . 33

3.9.1. Amostragem foliar. . . . . . 34

3.9.2. Anālise química das folhas. . . . 34

3.10. Levantamento da produção por he"ctare... . 35

4. RESUltados............................. 36

4.1. Explanações gerais e Anälise Estatística ... 36

4.2. Tabela e gráficos respectivos, relativos ao

Sub-Capítulo 5.1................ 45 
-ve.

4.3. Tabela e gráficos respectivos, referentes ao Sub-Capítulo 5.2. . . . . . . . . . 4 48

4.4. Tabelas e respectivos gräficos, referentes ao - Sub-Capítulo5.3. .............

4.5. Tabelas e respectivos gráficos, relativos ao Sub-Capítulo 5.4. . . . ....... . . 58

4.6. Fotos do experimento. . . . . . . . . 62

5. DISCUSSÃo . . . . . . . . . . . . . . 67

5.1. Relação entre altura média das plantas e os respectivos tratamentos aplicados. . . . . 67

5.2. Relação entre produção média por hectare, e as diferentes fontes, de aplicação e quantidä. des de Cálcio e de Enxofre, aplicadas ao solo.

5.3. Relação entre teor dos elementos encontradona folha, e o teor destes mesmos elementos apli cado ao solo. . . . . . . . . . . .

5.3.1. Teores foliares de Cálcio......

5.3.2. Teores foliares de Enxofre. . . . 73

5.3.3. Teores foliares de $\mathrm{N}, \mathrm{P}, \mathrm{K}$ e $\mathrm{Mg} \cdot . \cdot .74$

5.4. Relação entre teor dos elmentos encontrados nas folhas, e as respectivas produções médias obtidas.................... . . . 75

5.4.1. Teores foliares de Cálcio.......

5.4.2. Teores foliares de Enxofre. . . . . 77 


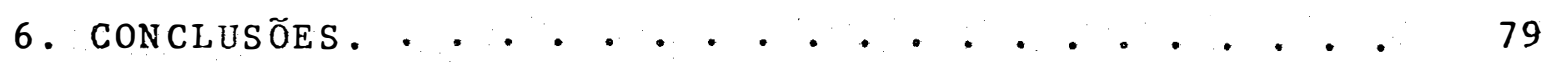

6.1. Conclusões referentes à altura média das plan tas......................... 79

6.2. Conclusões referentes à produção média por hec tare................... . .

6.3. Conclusões referentes aos teores foliares dos elementos, em função das quantidades em que fó ram aplicados ao solo............

6.4. Conclusões referentes aos teores foliares de Cálcio e de Enxofre, e as respectivas. produ ções médias por hectare. . . . . . . . . . 84

7. BIBLIOGRAFIA. • . . . . . . . . . . . . 86 
EFEITOS dO GESSO COMO FONTE dE CÁLCIO E dE

ENXOFRE NA CULTURA DA CANA-DE-AÇUCAR

(Saccharum of ficinarum L.)

\section{FRANCISCO ALFREDO FERNANDES}

FRANCISCO DE ASSIS FERRAZ DE MELLO ORIENTADOR

RESUMO

Foi estudado o efeito do gesso como fonte de cálcio e de enxofre para a cana-de-açucar.

O experimento foi conduzido na Fazenda Experi mental da Escola Superior de Agronomia de Paraguaçu Paulista situada no município de Paraguaçu Paulista, que tem as se guintes coordenadas geogräficas: $22^{\circ} 24^{\prime}$ de latitude sul e $50^{\circ} 34^{\prime}$ de longitude oeste. A altitude é de $505 \mathrm{~m}$.

O solo é o Latossolo Vermelho Escuro, textura uédia.

As variedades de cana utilizadas foram a NA5679 e a $C B-4176$. 
o gesso foi aplicado de três modos: como en chimento da fórmula NPK, em cobertura e no sulco de plantio.

Foram utilizados também tratamentos em que o enxofre foi empregado nas formas elementar e de sulfato de amônio bem como um tratamento testemunha na qual a fonte de nitrogênio foi a urēia.

Todos os tratamentos receberam fósforo na for ma de superfosfato triplo e potássio na forma de cloreto.

As principais conclusões podem ser resumidas do seguinte modo:

a) O gesso aplicado em cobertura na dose de $500 \mathrm{~kg} / \mathrm{ha}$ promoveu significativo aumento de produção.

b) o gesso se revelou bom material para enchi mento da fórmula de adubação no que se refere à elevação da produção.

c) o gesso, de um modo geral, causou aumentos nos teores de cālcio e de enxofre das folhas. 
EFFECTS OF GYPSUM AS A SOURCE OF CALCIUM AND SULFUR FOR SUGAR CANE (Saccharum officinarum L:)

FRANCISCO ALFREDO FERNANDES

FRANCISCO DE ASSIS FERRAZ DE MELLO

AUTHOR

\section{ADVISER}

\section{SUMMARY}

Experiments to study the effects of gypsum as calcium and sulfur source for sugar cane were carried out at the experimental farm of the School of Agriculture of Paragua çu Paulista, located in Paraguaçu, São Paulo, $22^{\circ} 24^{\prime} \mathrm{S}$ and $50^{\circ} 34^{\prime} \mathrm{W}, 505 \mathrm{~m}$ height.

The sugar cane varieties $N A-5679$ and $C B-4176$ were planted in dark-red sandy 1atosol. Gypsum was applied as: mixed with NPK fertilizer, broadcast and in planting furrows. For comparative purposes, sulfur was also added as elemental sulfur and as ammonium sulfate in separate essays. Experiments using urea as a nitrogen source were the control. In all the cases phosphorus was applied in the form of triple superphosphate and potassium as $\mathrm{KCl}$. 
The main conclusions are:

a) Broadcast application of $500 \mathrm{~kg} / \mathrm{ha}$ gypsum and mixed with NPK fertilizer significantly increased crop. production.

b) Gypsum showed be a good material

c) In general, the application of gypsum increased leaf' concentration of calcium and sulfur. 


\section{INTRODUÇÃO}

Na busca de novas fontes de nutrientes para as plantas agrícolas, o homem viu-se obrigado a pesquisar os diversos materiais existentes potencialmente aproveitáveis.

Considerando-se as diferentes possibilidades tais como o lixo urbano reprocessado, escórias industriais, vinhaça, e outros materiais, despertou-se-lhe o interesse em pesquisar um material deveras interessante, que é o gesso (Sul fato de Cálcio), do qual se dispõe em grande quantidade, nes te país, sob a forma de resíduo da indústria de fertilizan tes. Este material recebeu a designação específica de Fosfo GESSO, e é o sulfato de cálcio obtido como subproduto da ob tenção do ácido fósforico, utilizadona fabricação do super 
fosfato triplo, fosfatos de amónio, MAP e DAP. E um material que apresenta características químicas e físicas bastante fa voráveis à sua utilização na agricultura.

o Gesso é fonte de dois nutrientes essenciais às plantas, que são o Enxofre e o Cálcio. Ambos são considera dos macronutrientes, ou seja, elementos exigidos em quantida des relativamente grandes pelas plantas. Não obstante, sabese que até o presente momento, este material, pelo menos po tencialmente nutritivo, não vem sendo utilizado de forma sig nificativa na agricultura. Sabe-se tambēm, que o Brasil impor ta anualmente grandes quantidades de Enxofre na forma elemen tar, que, entre outras finalidades, é utilizado largamente na fabricação de adubos sulfurados tais como o sulfato de amô nio, o sulfonitrato de amônio, superfosfato simples, e ou tros.

Por outro lado, calcula-se que quando todas as fábricas brasileiras de superfosfato triplo e de fosfatos de amônio estiverem em plena produção, haverā anualmente uma quantidade de Gesso (Fosfogesso) acumulada sob a forma de re síduo, da ordem de sete milhões de toneladas, que corresponde a mais de um milhão de toneladas de Enxofre, ou seja, três ve zes a necessidade de enxofre das culturas de todo o país. De vido a isto, a indústria já está tomando providências para mu 
dar seus processos de fabricação, a fim de evitar o desperdí cio representado pelo não aproveitamento do Gesso.

Pesquisando-se a possibilidade de utilizar ra cionalmente o Gesso na agricultura, visando o aumento da pro dutividade, estudou-se neste trabalho, o seu aproveitamento pela cana-de-açúcar, cultura esta bastante exigente em enxo fre. Da mesma forma, pesquisando-se a possibilidade de se utili zar este material em diversas outras culturas, poder-se-á no futuro, reduzir-se o volume das importações de Enxofre, fato que sem dúvida contribuirá para o abaixamento das despesas ex. ternas do país, ao mesmo tempo que reduzirä custo de produ ção de diversas culturas exigentes em Enxofre, como è o caso da cana-de-açücar.

A pesquisa sobre a utilização do Gesso n a agricultura encontra-se atualmente em seus primeiros estágios. Não obstante, o que foi pesquisado até o momento revelou ma ior número de resultados favoráveis, em relação a alguns pou cos e pouco significativos resultados desfavoráveis.

Na cultura da cana-de-açúcar, pouco se sabe a respeito do seu aproveitamento, por enquanto. Sabe-se porém, que esta planta é bastante exigente em Enxofre, tanto ou mais do que em fósforo (macronutriente).

Sob o ponto de vista econômico, è muito mais 
vantajoso aplicar o Gesso como fonte de enxofre, do que apli car os adubos comerciais que contém esse elemento, uma vez que estes ültimos são muito mais ćaros.

Sabemos hoje que o Gesso já era utilizado co mo adubo pelos gregos e pelos romanos, na antigüidade. 0 seu valor agrícola no continente americano, conta a tradição, foi demonstrado por Benjamin Franklin, nos Estados Unidos da Amé rica do Norte. Na encosta de uma colina ele aplicou gesso, criando a frase:

\section{"This Zand has been plastered"}

que quer dizer, "Este solo foi gessado". O maior crescimento da pastagem na ärea que recebeu o Gesso serviu para demons trar a sua eficiência como adubo.

o exposto permite concluir que o Gesso não é um material qualquer, que se possa desprezar sem qualquer pes quisa, pelo contrário, é um material cuja potencialidade como fornecedor de elementos nutrientes importantes quais sejam o Enxofre e óálcio, para as culturas, deve levar o pesquis a dor consciente a estudā-lo com a máxima seriedade e dedica ção.

Testando-se diferentes fontes, diferentes for mas de aplicação, e diferentes quantidades de Cálcio e de En 
xofre, na cultura de cana-de-açúcar (em duas variedades dife rentes), o presente trabalho teve por objetivos:

19 Observar o desenvolvimento da cultura da cana-de-açúcar, em determinada fase do seu desenvolvimento (no caso, aos três meses de idade), através da altura média das plantas;

20 Observar a produção mëdia por hectare;

30 Observar a relação entre a produção média por hectare e o teor foliar dos elementos aplicados ao solo;

40 Observar a relação entre o teor dos elemen tos aplicados ao solo, e o teor desses mesmos elementos, en contrados nas folhas. 
A literatura mundial e brasileira sobre a ut lização do gesso na agricultura, suas implicações econồmicas, seu comportamento no solo, seu potencial como adubo, seu apro veitamento pelas plantas, em fim, seu real valor na agricultu ra, encontra-se ainda, praticamente, na sua fase inicial de pesquisa, necessitando, portanto, de estudos mais aprofunda dos. A presente revisão de literatura procurou abordar os as pectos importantes, relacionados com a questão, voltando seu enfoque principalmente sobre a cultura da cana-de-açúcar, planta teste utilizada neste experimento. 


\section{a) VALOR AGRTCOLA DO GESSO}

Como já foi visto na primeira parte deste tra balho, a utilização do gesso pelo homem, na agricultura, re monta aos tempos mais antigos, porém, os trabalhos pioneiros no âmbito científico são relativamente recentes.

CASTILLA (1954), HERANDO et a $i i$ (1963), MEL LO et alii (1974) e MALAVOLTA et alii (1979) são unânimes em afirmar que o elevado pH dos solos alcalinos é reduzido a um valor adequado à vida das plantas agricultäveis, em decorrên cia da aplicação de doses maçiças de gesso (2 a 5 ton/ha), se guidas de irrigação abundante para intensa lixiviação do per fil, e conseqüente drenagem, para eliminaça dos sais dissol vidos.

Tal não acontece nos solos não-alcalinos, on de as doses aplicadas de gesso são bem menores, relativamen te, ao redor de 300 a $600 \mathrm{~kg} / \mathrm{ha}$, como adubo (JONES e RUCKMAN, 1969; MALAVOLTA et aZii, 1979;. FERNANDES, 1982):

A absorção do Zn pelo arroz foi favorecida pẹ 10 abaixamento do $\mathrm{pH}$ em solos alcalinos, mediante a aplicação de diferentes doses de gesso, TAKKAR e SINGH (1978).

$\mathrm{Na}$ cultura do amendoim, o gesso pode ser apli cado ao lado das plantas, antes da amontoa, ou seja, por oca sião do florescimento (FERREIRA et alii (s.d.). Conforme es 
tes autores, é uma prática que ajuda a reduzir a porcentagem de flores abortadas, concorrendo assim, para o aumento da pro dução.

A a lfafa é uma das plantas que mais prontamen te respondem à aplicação do gesso, ERDMAN E BOLLEN (1925), cí tado por MALAVOLTA (1976, pg. 181).

CONRAD, citado por JONES e RUCKMAN (1966), rea lizou estudos comparativos entre a superficie aplicada de ges so e a de enxofre na forma elementar, visando estabelecer uma correlação que servisse de base para tais estudos. Nestes ex perimentos, o enxofre aplicado na forma elementar estimulou o aumento das produções, com eficiência aproximadamente igual àquelas obtidas da aplicação do enxofre contido no gesso, ex ceto nas āreas (regiões) de precipitação limitada. Sob es tas condições, as parcelas que receberam gesso sobrepujaram as parcelas que receberam o enxofre na forma elementar.

$$
\text { Os pesquisadores MAY, TILL e DOWNES (1967), }
$$

estudando a viabilidade do uso do gesso em pastagens, e utili zando enxofre marcado $\left(\mathrm{S}^{35}\right)$, observaram que, mesmo após dois anos da aplicação, ainda havia no solo, enxofre em quantida des suficientes para atender as exigências nutricionais das plantas.

Testando o efeito da aplicação do gesso como 
fonte de enxofre na cana-de-açücar, HOWES (1967) não consta tou nenhuma diferença, em termos de aumento de produção elou do teor de sacarose, nos tratamentos que receberam o enxofre, puramente na forma elementar. Verificou aumentos destes valo res, entretanto, nos tratamentos que receberam o enxofre con tido no gesso.

Com o fim de comparar os efeitos da aplicação de enxofre, na forma elementar e enxofre contido no gesso, terido padronizado a granulometria destas partículas, JONES e RUCKMAN (1969) observaram que a absorção do enxofre aplicado ina forma elementar, proveniente das menores partículas, foi relativamente maior. Ainda conforme estes autores, a absorção do enxofre contido no gesso mostrou resultado semelhante, ten do sido porém, relativamente mais rápida, a diminuição deste no solo, e, ao final de quatro anos de experimento, a produ ção de forragens obtida pelos tratamentos com gesso, superou a todos os demais tratamentos.

Estudos feitos por REEVE e SUMNER (1972) mos traram que o gesso incorporado às camadas superficiais do so 10 tem a capacidade de, atingindo camadas mais profundas, pro mover nestas a diminuição da saturação de alumínio, reduzindo desta forma a toxidez provocada pelo excesso deste elemento. 
b) IMPORTANCIA DA RELAÇAO ENTRE O USO DO GES SO E OUTROS ADUBOS PORTADORES DE ENXOFRE, E O USO DE FERTILIZANTES NITROGENADOS NA CANA DE AÇOCAR.

Segundo LIPMAN (1911), citado por Malavolta (1976), quando se usa o S elementar na adubação, ele se trans forma no solo, através dos microorganismos, da seguinte for ma :

$$
\begin{gathered}
\mathrm{S}+\mathrm{H}_{2} \mathrm{O}+\mathrm{O}_{2} \rightarrow \mathrm{H}_{2} \mathrm{SO}_{3} \\
\mathrm{H}_{2} \mathrm{SO}_{3}+\mathrm{CaH}_{2}\left(\mathrm{CO}_{3}\right)_{2}+\mathrm{CaSO}_{3}+2 \mathrm{H}_{2} \mathrm{O}+2 \mathrm{CO}_{2} \\
2 \mathrm{CaSO}_{3}+\mathrm{O}_{2}+2 \mathrm{CaSO}_{4}
\end{gathered}
$$

WAKSMAN (1927), tambēm citado por MALAVOLTA (1976), recomenda a adição de microorganismos oxidantes ao en xofre em pó, quando este é aplicado ao solo, com o fim de ob ter uma mais completa oxidação do material, sendo o mais indi cado para isto o Thiobacillus thiooxidans.

Ainda, conforme MALAvolta (1976), a oxidação do enxofre elementar a ácido sulfúrico possibilita o aprove tamento do S. A acidez limita, naturalmente, a possibilidade de se usar quantidades muito grandes deste material, uma vez que o abaixamento demasiado do pH pode criar condições desfa voráveis à vida das plantas. 
Sobre o fracionamento do $\mathrm{N}$ em cana-planta em Terra Roxa, ALVAREZ et a $i i i$ (1963) observaram que as produ ções devidas aos parcelamentos não diferiram entre si, com ex ceção da dose menor de $N$ aplicada aos 2,5 meses, que foi infe rior."

Conforme HUMBERT (1968), nem sempre diferen tes variedades de cana-de-açücar respondem de modo similar a. uma mesma adubação.

0 uso contínuo de fertilizantes isentos de e $\underline{n}$. xonfre, tais como a uréia e a amônia, faz aumentar a possibi lidade de aparecimento dos sintomas de deficiência deste ele mento na cana-de-açūcar, SEDL (1968).

Estudando os efeitos da deficiência do $S$ na cana-de-alúcar, GOSNELL e LONG (1969), mostraram que estes efeitos somente surgiam após 4 a 5 anos, como decorrência do uso contínuo de fertilizantes isentos deste elemento. Segundo estes pesquisadores, basta uma aplicação moderada de enxofre $(25-50 \mathrm{~kg} / \mathrm{ha})$, para se obter prontos efeitos, como o aumento do teor de sacarose e aumento da intensidade do verde das fo 1 has.

\section{Em artigo publicado no International Sugar} Journal, ANônIMO (1970), discute a necessidade do enxofre na nutrição dá cana-de-açúcar, concluindo que a sua deficiência 
nesta cultura em diversos casos, é decorrente do uso prolonga do de fertilizantes is entos deste elemento.

Em experimento levado a efeito em vasos, con tendo terras de várzeas do Pará, WANG et alii (1976) verifica ram que o emprego de adubos com nitrogênio, fósforo e potás sio, e isentos de enxofre em sua composição, fez com que a co 1heita de arroz caísse de 6-7 para 2-3 toneladas por hectare, após 3 anos de cultivo. Complementando a deficiência do enxo fre nestes adubos utilizando para tanto, o enxofre contido no gesso, observou-se um significativo aumento da produção, au mento este, naturalmente devido também à influência do cá cio, que também faz parte da composição química do gesso.

c) MATERIAIS QUE PODEM SER APLICADOS JUNTAMEN TE COM O GESSO

Durante o processo fermentativo do esterco, seja qualfor a sua origem, ocorre perda do $N$ na forma de amô nia, em até quase $60 \%$ num período de 4 meses. Conforme MALA VOLTA et alii (1979), esta perda é possível de ser evitada se se juntar superfosfato simples ou gesso ao esterco, uma vez que estes materiais têm a propriedade de "fixar" a amônia, na forma de sulfato de amônio.

De acordo com dados fornecidos pelo Instituto de Zootecria do Estado de São Paulo, o gesso pode ser mistura 
.13.

do ao fosfato natural, sem nenhum inconveniente, uma vez que ambos os materiais se acham na forma de pó. Efeitos favoráveis foram observados na produção do capim colonião.

PONTE et ali (1978) demonstraram que o gesso pode ser muito bem aplicado, junto com o calcario, desde que as proporçoes da mistura sejam adequadas. Neste caso, a dose equivalente à necessidade de cal foi a que melhor resultado apresentou, acarretando a maior produção de soja. No caso do trigo, que é uma gramínea, a dose de gesso equivalente a duas vezes a necessidade de cal, foi a que maior produção de grãos apresentou. Atribuíram estefeito à presença do enxofre, uma vez que o calcário aplicado sem gesso demonstrou resultados re lativamente inferiores.

d) O GESSO, FONTE DE Ca E DE PARA AS PLAN TAS

O Quadro 1 apresentado a seguir, mostra a 1 guns adubos portadores de enxofre, incluindo o gesso, extraído de MALAVOLTA, E. 1976. p- 183.

Mc CLUNG e QUINN (1959), citados por MALAVOL TA (1976), mostraram que o gesso foi tão eficiente quanto o sulfato de sódio ou o enxofre elementar para corrigir deficiên cia desse elemento em grama "batatais" cultivada no Arenito de Bauru, tipo de solo do Estado de São Paulo. 
Quadro 1 . Teor de enxofre em alguns fertilizantes comerciais.

Gesso.................... 20,5

Sulfato de amônio. . . . . . . 24,0

Superfosfato simples.... . . 11,6

Sulfato de potásio ....... 18,0

Sulfato de potássio e magnésio.. 23,0

Sulfonitrato de amônio ........ 18,0

Tanto o enxofre elementar quanto o enxofre con tido no gesso são duas fontes igualmente efetivas no aumento da produção de plantas forrageiras, JONES e RUCKMAN (1966).

Em experimentos conduzidos na Califórnia, BEN TLEY e GREEN, citados por JONES e RUCKMAN (1966) não registra ram quaisquer diferenças nas respostas de gramíneas anuais, quan do o enxofre foi aplicado como gesso, como enxofre elementar ou como superfosfato simples.

POONIA e BHUMBLA (1972), estudando os efeitos da aplicação do cálcio contido no gesso; utilizando gesso mar cado $\left(\mathrm{Ca}^{45}\right)$, em milho, registraram significativo aproveitamen to deste nutriente contido no gesso, por estas plantas. 
.15 .

o enxofreé diretamente responsável pelo au mento da produção da cana-de-açücar, assim como no aumento do teor de sacarose desta cultura, ANDREIS (1975).

o gesso é fornecedor, tanto de enxofre (S) co mo do cálcio ( $C a)$, que são considerados como macronutrientes, isto é, elementos que as plantas necessitam em quantidade rela tivamente grandes (MELLO et alii, 1974 ; MALAVOLTA et alii, 1979).

Para a maioria das plantas cultivadas, as exi gências de cálcio são menores que as do potássio, porém, em al gumas culturas como a cana-de-açúcar, batatinha, algodoeiro, feijoeiro, cebola, couve-flor, tomateiro e cafeeiro, as neces sidades de enxofre são maiores do que as de fósforo, MALAVolta et alii (1979).

e) DIAGNOSE FOLIAR NA CANA-DE-AÇOCAR

GALLO et alii (1968), observaram que os teo res médios dos elementos encontrados na diagnose foliar em ca naviais, variam conforme o tipo de solo. Constataram diferen ças também, nas amplitudes de variação dos teores dos elemen tos ao comparar cana planta com cana soca.

Segundo MALAVolta et alii (1972), o nümero de folhas que se tira para análise depende muito da uniformidade 
do talhão, devendo ser tiradas em média 20 folhas por hectare. Para ORLANDO F. e CAMPOS (1975), entretanto, seriam suficien tes apenas 2 folhas por hectare para representa- 1 a.

Destaca-se a diagnose foliar entre os diver s.os métodos utilizados para a determinação das necessidades de fertilizantes para a cultura, método este, que se baseia na re lação entre o teor do elemento na folha e a produção. Esse va lor, quando comparado a um padrão previamente estabelecido, po de indicar, segundo alguns autores, a quantidade de fertilizan tes necessāria para se alcançar determinada produção (HAAG e ORLANDO FILHO, 1976).

A época de se fazer a amostragem para a diag nose foliar é também importante, uma vez que os teores dos nu trientes nas folhas é variável conforme a idade da planta. os experimentos desenvolvidos por ORLANDO FILHO (1978) mostraram que, para a cana-de-açúcar, o teor tende a diminuir entre os 4 e 8 meses, após o que, um aumento até os 12 meses, e então no vo decréscimo até a colheita. Tais variações coincidem com es tações secas e chuvosâs, devendo portanto haver relação entre os fatos.

Para a diagnose foliar da cana-de-açúcar, são geralmente determinados os teores totais dos elementos, com o que então, se estabelece uma relação com a produção. TEIXEIRA 
.17.

(1980), entretanto, constatou existir melhor correlação entre - teor de $N$ amoniacal encontrado nas folhas e a produção, do que a existente entre $N$ total nas folhas e a produção.

Estudos levados a efeito por ZAMBELLO JR. et alii (1981), mostraram que a amostragem para diagnose foliar na cana soca, pode ser feita, sem qualquer inconveniente, aos 4 meses de idade, da mesma forma como se faz na cana-planta. 


\section{MATERIAL E METODOS}

3.1. Local

o presente experimento foi instalado em um campo experimental situado na fazenda da Escola Superió de Agronomia de Paraguaçu Paulista (ESAPP), no múnicípio de Para guaçu Paulista, tendo como coordenadas geográficas, latitude de $22^{\circ} 24^{\prime} \mathrm{L} / \mathrm{S}$ e longitude de $50^{\circ} 34^{\prime} \mathrm{W}$, com altitude de 505 me tros sobre o nível do mar.

3.2. Solo

$$
0 \text { solo, onde se desenvolveu o experimento, }
$$

foi submetido à anālise de fertilidade, no laboratório de aná 
lịse de solos do Centro de Estudos de Solos da ESALQ-Universidade de São Paulo. Conforme a Comissão de Solos (1960), re beu a designação de Latossol Vermelho Escuro, fase arenosa, (ao nível de grande-grupo), representando aproximadamente $90 \%$ da ărea do município, e $19,7 \%$ na àrea do grande grupo latossó 1ico (MONIZ, 1975, p. 385). Entretanto, segundo dados extraí dos de DEMATÊ (sem data), baseados no "Soil Taxonomy", este solo, em virtude de sua pequena porcentagem de argila no per fil, não se enquadra na definição de Latossol, sendo classifi cado, mais precisamente (ao nível de sub-grupo), coma um "arenic Quartzipsament".

As anālises, de granulometria, densidade e consistência foram baseadas nos métodos descritos por KIEHL (1979). A análise do tipo, classe e grau de estrutura, foi ba seada em MONIZ (1975), enquanto que a descrição das cores foi feita através do sistema Münsel1 (MUNSELl SOIL COLOR CHARTS, 1975). A coleta das amostras de solo, no campo, seguiram as instruções dadas em LEMOS e SANTOS (1976).

A anālise química do solo, revelou os dados que são apresentados na Tabela 1 eonforme se vê na pägina se guinte.

A determinação do $\mathrm{Ca}^{++}$e do $\mathrm{Mg}^{++}$obedeceu ao método proposto por LIMA FILHO (1977), enquanto que as demais. 


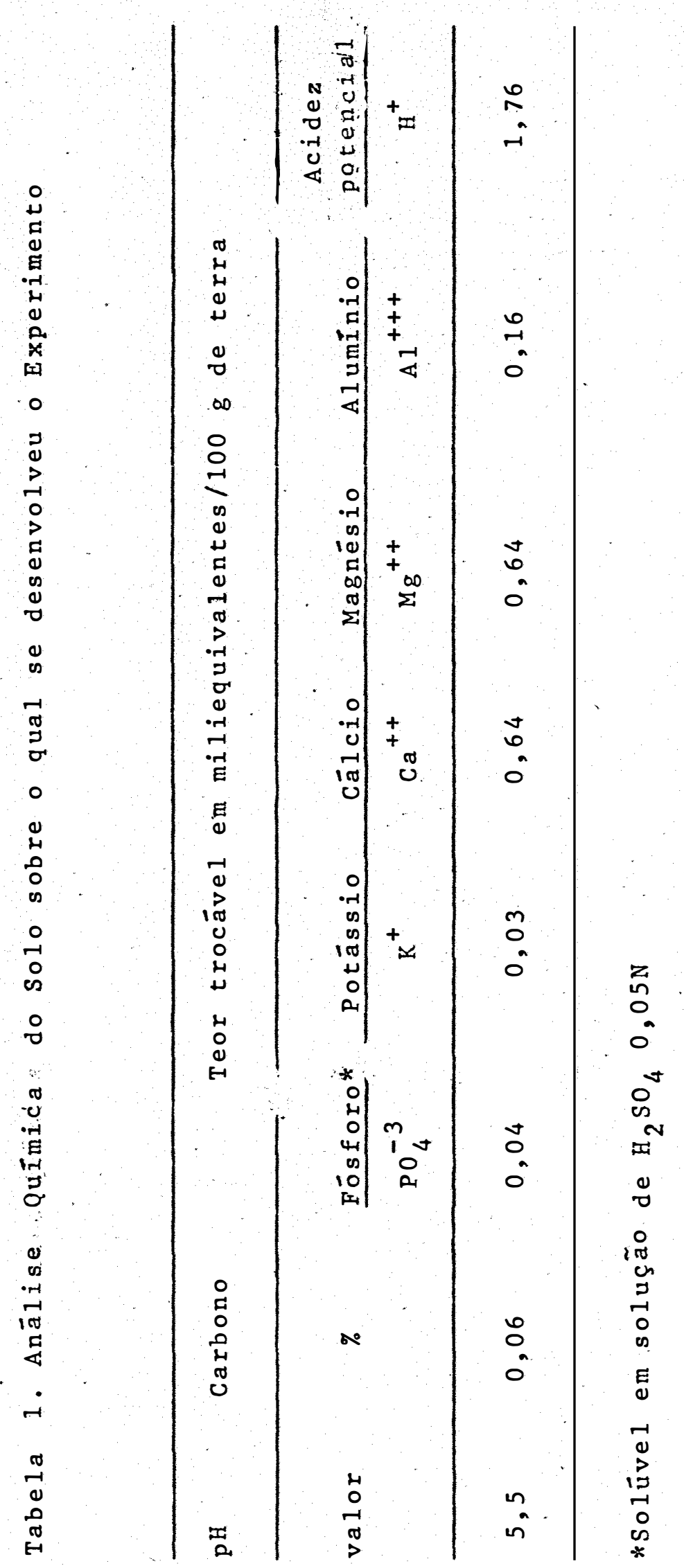


determinações seguiram os métodos propostos por CATANI e JA CINTHO ( 1974$)$.

A partir dos dados revelados pela análise quí mica do solo, foram feitas as recomendações de adubação, aplicada nos - tratamentos, conforme no BoLETIM no 209 , do Instituto Agronômico de Campinas (TABELAS DE ADUBAÇÃo E CA LAGEM) publicado em 1977, e tambēm através dos resultados das pesquisas desenvolvidas por SILVEIRA et ali $i$ (1978). As carac terísticas dos diferentes adubos utilizados, foram reconheci das através do Manual de Adubação (ASSOCIAção NAĊIONAL PARA DIFUSÃO DE ADUBOS, 1975 ).

\subsection{Ciima}

O clima do município de Paraguaçu Paulista é do tipo mesotérmico, Cwa, pelo sistema köpen, ou seja, subtro pical úmido com estiagem no inverno, sendo que as chuvas do mês mais seco, não atingem 30 milímetros.

Durante dez meses em que o experimento foi de senvolvido, (de Agosto de 1981 a Maio de 1982), a precipita ção pluviométrica total, foi de $1.850,6 \mathrm{~mm}$; a temperatura mê dia mensa 1 , de $22,7^{\circ} \mathrm{C}$; a temperatura média máxima (mensa1), de $30,6^{\circ} \mathrm{C}$, enquanto que a temperatura média mínima (mensa 1 ), foi de $15,6^{\circ} \mathrm{C}$; a umidade relativa média (mensal) foi de $76,3 \%$, 
ao passo que o nümero mensal (médio) de horas de insolação foi de 177,4 horas, tendo sido 5,8 horas, o nümero médio diá rio, de horas de insolação (dados fornecidos pelo posto meteo rológico da ESAPP). Estes dados são apresentados na Tabela 2 .

\subsection{Variedades Estudadas}

Os mesmos tratamentos foram aplicados simulta neamente, em duas variedades diferentes de cana-de-açūcar, a CB4176 e a Na5679.

Conforme descreve FERNANDES (1984, p. 14), re ferente à variedade $C B 4176$, o rendimento agrícola tanto para a cana-planta como para a cana-soca é bom, e o teor de açúcar é médio. o PuI (período ūtil de industrialização) é curto, e a maturação para todos os cortes é mediana. A brotação e o perfilhamento são bons. Não é exigente em solos, porém, é mui to sensível à seca e ao frio, não se aconselhando a plantála em baixadas ou beiradas de água. Quanto às doenças ela se mostra resistente ao carvão, ao mosaico e à mancha parda. E intermediariamente resistente à escaldadura e à mancha ocular. E suscetível à podridão vermelha e ao raquitismo das soque ras. Mostra-se pouco resistente ao ataque da broca e suscetí vel ao at aque do nematóide Meloidogyne.

A despalha é regular, não acama, não floresce 


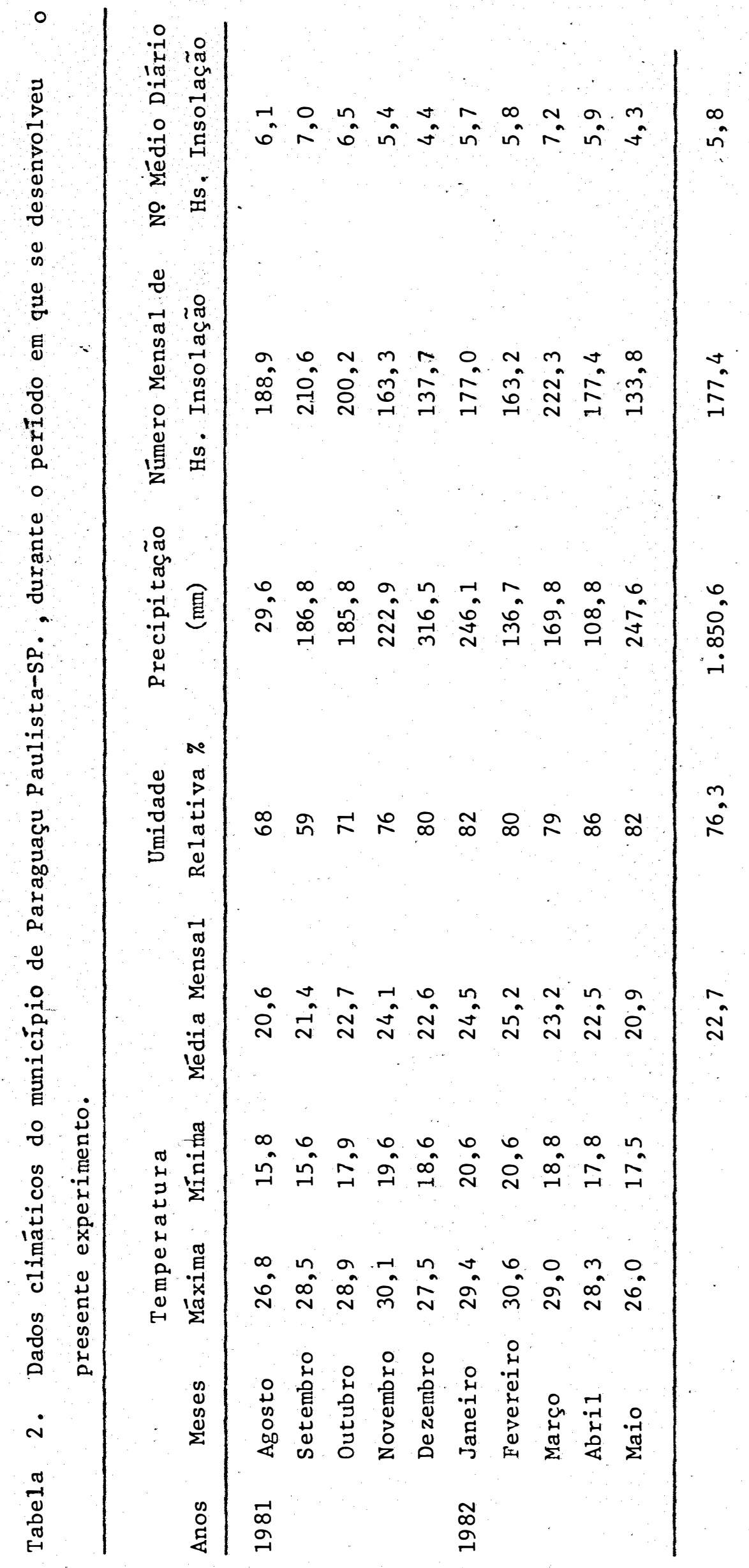


e apresenta pouco joçal. o formato da gema é oval-alongado. o colmo é roxo-esverdeado, de diâmetro médio e de dureza média. A folha é arqueada e de largura média. Apresenta pouco caldo e teor de fibra médio.

Com respeito à outra variedade utilizada nes te experimento, a NA5679, o mesmo autor, (FERNANDES, 1984 p. 26), assim a descreve: o rendimento agrícola é bom tanto para a cana-planta como para as socas. o teor de açücar é alto. o PUI (período útil de industrialização) da cana-planta varia de médio a longo, e o da cana-soca é longo. A maturação se dá precocemente. A germinação e o perfilhamento são apenas regü lares, enquanto a brotação da soqueira é muito boa. É pouco exigente em solos e é resistente à seca.

No aspecto fitopatológico é resistente à man cha parda. E intermediariamente resistente à escaldadura, ao mosaico, podridão vermelha, mancha ocular e a carvão. E sus cetível ao raquitismo das soqueiras. Não oferece resistência ao ataque da broca, e intermediariamente tolerante ao nematói de Meloidogyne.

Despalha facilmente, acama pouco, floresce in tensamente e não tem joçal. A gema é oval alongada e o colmo é verde arroxeado, de diâmetro médio e dureza média. A folha é fina e palmito é curto. Como característica apresenta um Wigue-zague formado pelos entrenós do colmo. Possui bastante 
caldo e teor da fibra médio.

As características agro-industriais das duas variedades de cana-de-açúcar estudadas, são apresentadas na Tabela 3 .

$\because$

As caracteristicas genéticas das duas varieda des de cana-de-açūcar estudadas, são apresentadas na Tabe1 a 4 .

\subsection{Desenho Experimental}

Utilizou-se o alineamento experimental de blocos ao acaso, com 8 tratamentos e 4 repetições. Para cada uma das duas variedades de cana-de-açūcar estudadas, foi montado o citado desenho experimental.

A ärea total ocupada pelo experimento foi-de $10.000 \mathrm{~m}^{2}$ (um hectare), cada bloco (conjunto de oito "parcelas) $520 \mathrm{~m}^{2}$, e cada tratamento ocupou uma ärea de $65 \mathrm{~m}^{2}$.

os tratamentos, visando testar a eficiência do gesso (fosfogesso) como fornecedor de cáicio e de enxofre à cultura da cana-de-açūcar, foram os seguintes:

Tratamento A 


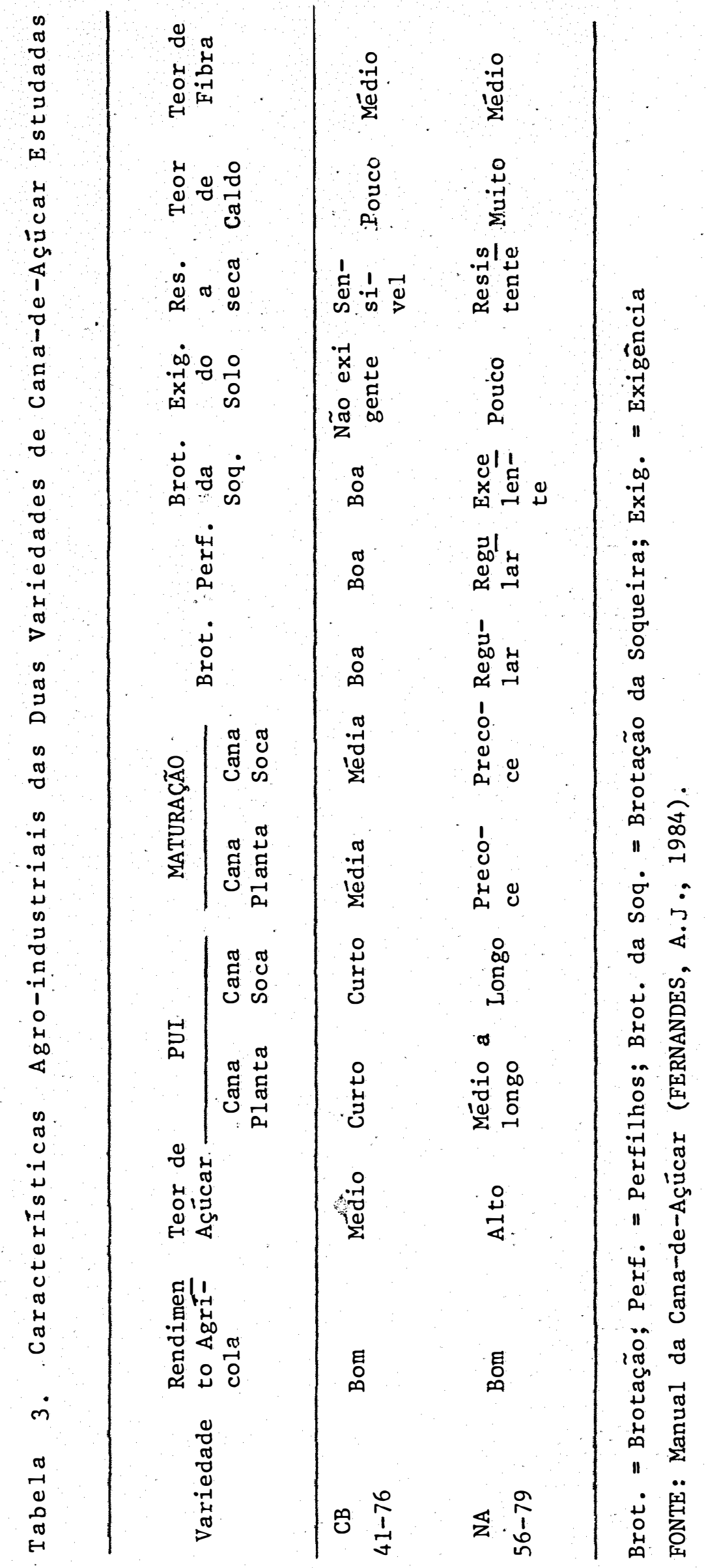




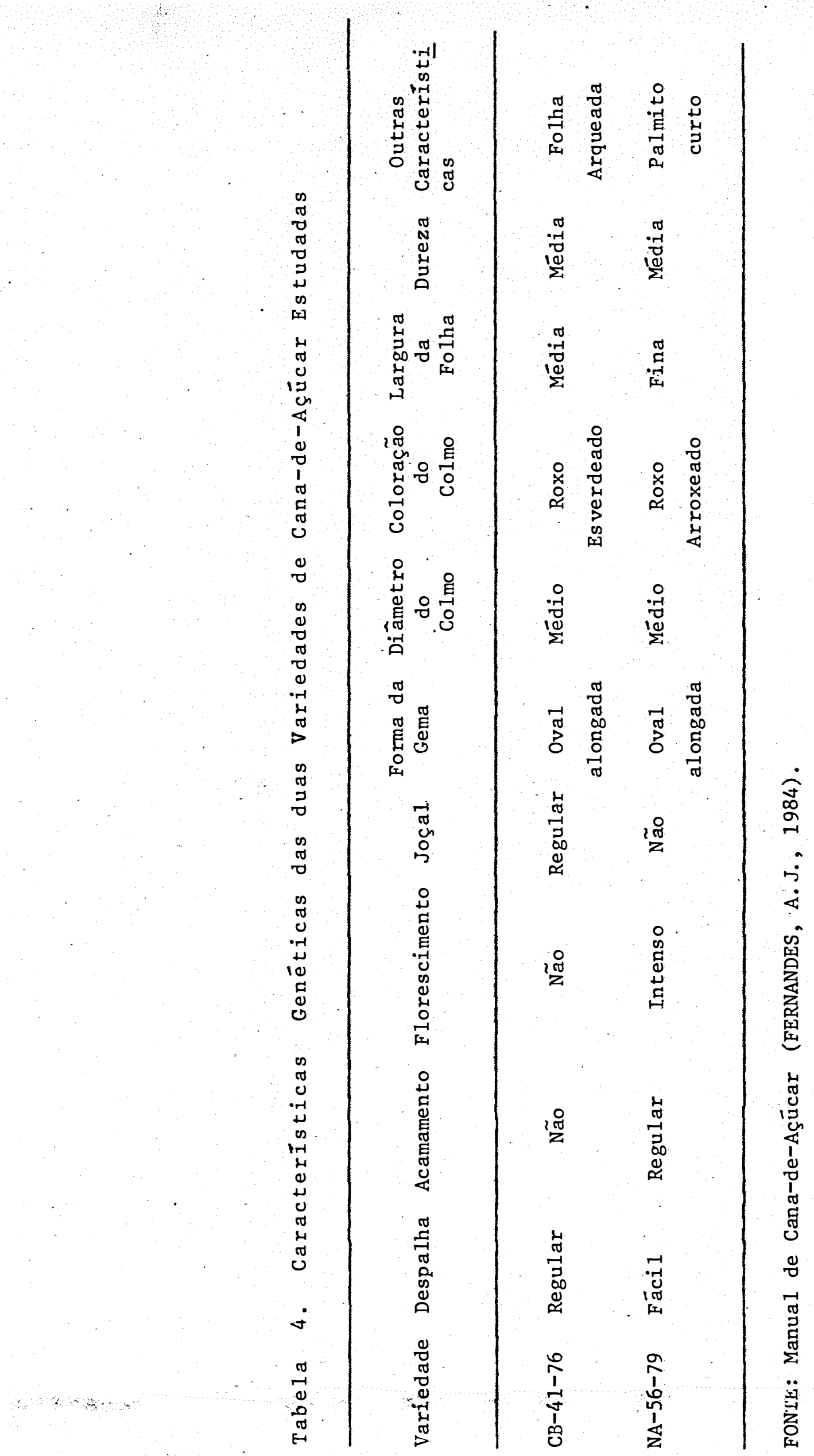


UREIA como fonte de nitrogênio, talco inerte como enchimento da fórmula, (zero de enxofre, e $5,5 k g / h a$ de cálcio).

\section{Tratamento B}

$$
\text { Adubação bāsica tendo-se usado sulfA }
$$

TO DE AMÔNIO como fonte de nitrogênio, talco inerte como en chimento da fórmula $(22,5 \mathrm{~kg} / \mathrm{ha}$ de enxofre, e $5,5 \mathrm{~kg} / \mathrm{ha}$ de cälcio).

Tratamento C

$$
\text { Adubação bäsicea tendo-se usado }
$$

UREIA como fonte de nitrogênio, e "FOSFOGESSO" como enchimen to da fórmula (118,4 kg/ha de enxofre e $210,5 \mathrm{~kg} / \mathrm{ha}$ de cálcio).

Tratamento D

Adubação básica …tendo-se usado SULFA TO DE AMÔNIO como fonte de nitrogênio, e "Fosfogesso" como en chimento da fórmula (132,0 kg/ha de enxofre e 195,5kg/ha de cá 1 cio).

\section{Tratamento $E$}

$$
\text { Adubação bāsica tendo-se usado a URE }
$$

IA como fonte de nitrogênio, talco inerte como enchimento da 
fórmula e $50 \mathrm{~kg} / \mathrm{ha}$ de "FOSFOGESS" no sulco de plantio $\quad(7,5$ $\mathrm{kg} / \mathrm{ha}$ de enxofre e $18,5 \mathrm{~kg} / \mathrm{ha}$ de cálcio).

Tratamento $F$

Adubação básica tendo-se usado a URE

IA como fonte de nitrogênio, talco inerte como enchimento da förmula, e $50 \mathrm{~kg} / \mathrm{ha}$ de enxofre elementar no sulco de plantio ( $30 \mathrm{~kg} / \mathrm{ha}$ de enxofre e $5,5 \mathrm{~kg} / \mathrm{ha}$ de cálcio).

\section{Tratamento G}

$$
\text { Adubação bāsica t tendo-se usado a URE }
$$

IA como fonte de nitrogênio, talco inerte como enchimento da fórmula, e $500 \mathrm{~kg} / \mathrm{ha}$ de "Fosfogesso" aplicado em cobertura, logo após o plantio (75 kg/ha de enxofre e $135,5 \mathrm{~kg} / \mathrm{ha}$ de cá1 cio).

Tratamento $H$

$$
\text { Adubação bäsića tendo-se usado a URE }
$$

IA como fonte de nitrogênio, talco inerte como enchimento da fórmula, e $500 \mathrm{~kg} / \mathrm{ha}$ de enxofre elementar, aplicado em cober tura, logo após o plantio (300 kg/ha de enxofre e $5,5 \mathrm{~kg} / \mathrm{ha}$ de càtcio).

o Quadro 2 apresentado a seguir resumo o experimento. 
QUADRO 2 . Fontes, formas de aplicação e respectivas quanti dades de Cálcio e Enxofre aplicadas ao solo.

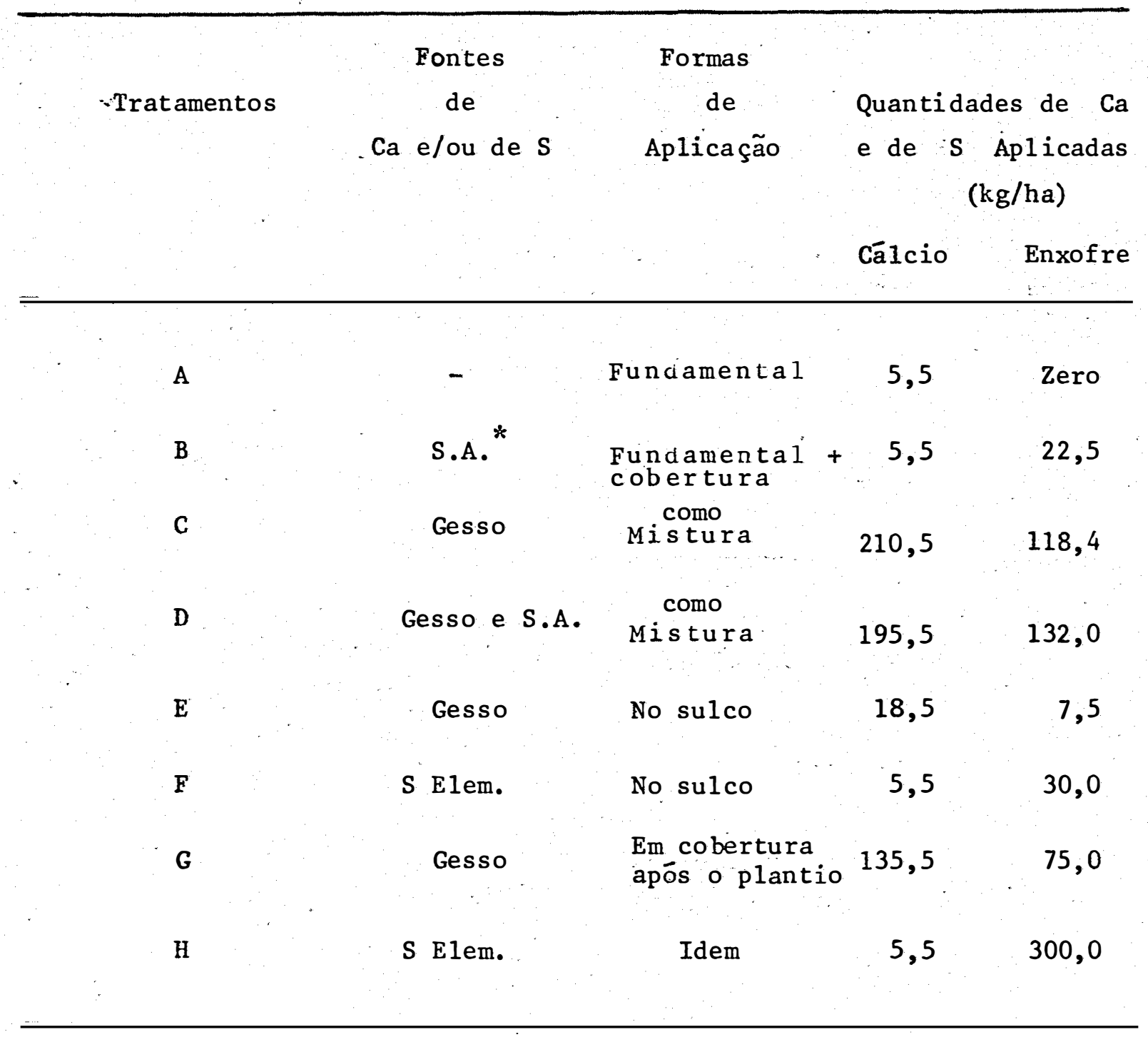

*S.A. = Sulfato de amônio; S Elem. = Enxofre elementar

3.6. Preparo do Solo e Demarcação do Experimento

Foram realizadas duas arações profundas, com 
arado de discos, seguidas de duas gradagens. Dez dias depois fez-se o sulcamento a $40 \mathrm{~cm}$ de profundidade e $1,30 \mathrm{~m}$ entre sulcos. A seguir foram delimitados os canteiros, experimentais de $10 \mathrm{~m} \times 65 \mathrm{~m}$ com enxada.

\subsection{Plantio}

Utilizou-se mudas selecionadas, na quantidade de 8 a 9 toneladas por hectare. As mudas foram colocadas no fundo dos sulcos, onde foram picadas em toletes de três ge mas, após o que, foram cobertas com terra, manualmente, com enxada. Foram colocadas aproximadamente $15 \mathrm{~cm}$ de terra, sobre as mudas.

0 plantio foi feito em fevereiro de 1981 (épo ca chuvosa). Entretanto, em fins de agosto deste mesmo ano, a ocorrência de uma forte geada destruiu todas as canas. Ten do sido ordenado o corte rasteiro de todas as plantas danifi cadas, as socas restantes brotaram novamente, originando no vas plantas, que receberam adubação nitrogenada em cobertura no início do rebrotamento. Como a geada foi um fator fixo pa ra todos os tratamentos, concluiu-se que o seu efeito foi igual para todos, não invalidando, portanto, o experimento.

$$
\text { Assim, esta cana que era a princípio, "cana }
$$
de ano-e-meio" devido ao ocorrido, passou a ser "cana-de-ano", cujo plantio é normalmente feito de setembro a outubro. 
- 32 .

Considerou-se, assim, como o tempo de duração do experimento, o período compreendido entre agosto de 1981 e maio de 1982 , quando foi feito o levantamento da produção por área' (produtividade).

\subsection{Adubação}

Foi feita adubação química conforme recomenda ção baseada nos dados revelados pela anālise de solo. A quanti dade aplicada $(\mathrm{N}-\mathrm{P}-\mathrm{K})$, preparada no 1 ocal, foi $30-20-60$ (kg/ha), de cada elemento respectivamente. Os adubos utilizados foram, uréia, sulfato de amônio, superfosfato triplo e cloreto de potássio. o nitrogênio foi aplicado parceladamente, sendo $1 / 3$ no plantio, e $2 / 3$ em cobertura, 60 dias após o plantio.

\subsubsection{Aplicação dos Tratamentos}

Os tratamentos (diferentes fontes de $S$ e/ou de Ca), foram aplicados manualmente, com o auxílio de copinhos comuns descartáveis. Os materiais que foram aplicados no fun do dos sulcos foram assim distribuídos o mais uniformemente possível, o mesmo tendo sido feito em relação ao gesso e enxofre que foram aplicados a lanço, após o plantio, em alguns trata mentos, também manualmente. 
3.8.2. Preparo dos Materiais Aplicados

Uma vez calculadas as quantidades a serem apli cadas de cada um dos respectivos materiais a serem testa dös, utilizou-se uma balança comum para a pesagem dos mes mos (pesagens diversas, variando em torno de 15 a $30 \mathrm{~kg}$ ). Todos esses materiais foram acondicionados em sacos plásti cos devidamente etiquetados (identificados), após o que, foram aplicados como devidos tratamentos.

Cada saco plástico recebeu 22 gramas de Aldrin a $5 \%$ (misturado ao seu conteúdo), com a finalidade de pre venção e controle contra as pragas do solo correspondendo à quantidade de $20 \mathrm{~kg} / \mathrm{ha}$ de Aldrin a $5 \%$.

\subsection{Diagnose Foliar.}

Existem normas a serem obedecidas, quando se faz a coleta das folhas para anālise foliar da cana $\widetilde{-d e-a c ̧ u-~}$ car, a fim de que se possa obter uma relativa uniformidade nos dados obtidos para diferentes variedades, em diferen tes épocas de amostragem, Assim, deve-se colher, para ana lise foliar da cana-de-açúcar, a folha +3 (folha que se 10 caliza logo abaixo das três folhas apicais), e quando a cana estiver 
com aproximadamente 4 (quatro) meses de idade.

\subsubsection{Amostragem Foliar}

No presente trabalho, tais normas não foram ri gorosamente obedecidas, tendo-se colhido para análise foliar, as quatro folhas mais novas (incluindo a folha +3), quando a cana estava com 9 (nove) meses de idade.

Esta amostragem foliar não deixa de ter, entre tanto, sua validade, uma vez que permitiräobter conclusões interessantes sob dois aspectos.

19 correlação entre o teor encontrado na folha de cada elemento \% em função da dose de ca da elemento aplicada ao solo (kg/ha);

29 correlação entre o teor do elemento encon trado na folha $\%$ e respectiva produção obti da (t/ha).

3.9.2. Anälise Química das Folhas

Procedeu-se à anālise química das follhas cole tadas, que foram primeiramente secas em estufa, após o que, 
foram trituradas em moinho elétrico, apropriado. o pó obtido foi recolhido em saquinhos limpos de papel, que devidamente identificados, foram encaminhados ao laboratório de análises do Centro de Energia Nuclear na Agricultura (CENA), onde fo ram analisadas.

3.10. Levantamento da Produção por Hectare

Para cada parcela de tratamento foi contado o número de canas por 10 (dez) metros (média de três amostragens). De cada uma destas parcelas, pesou-se 20 (vinte) canas, tiradas ao acaso, peso esse obtido em kg.

Como a área total coberta pelo experimento foi de $10.000 \mathrm{~m}^{2}$, e o espaçamento adotado entre sulcos, de 1,30 m, o cálculo para se obter a produção (toneladas/hectare) em cada tratamento, foi o seguinte:

$$
\begin{aligned}
\frac{10.000 \mathrm{~m}^{2}}{1,30 \mathrm{~m}} & =7.692 \text { metros lineares de sulco } \\
N Q \text { canas } / \mathrm{ha} & =7.692 \times \frac{\mathrm{N} \text { canas } / 10 \mathrm{~m}}{10} \\
\text { Produção (t/ha) } & =\frac{N Q \mathrm{canas} / \mathrm{ha} \times \mathrm{Pes} O 20 \mathrm{canas}(\mathrm{kg})}{20.000}
\end{aligned}
$$


4. RESULTADOS

4.1. Explanações Gerais

A fim de facilitar a observação e o entendi mento dos resultados do presente trabalho, os mesmos foram dispostos concisamente, na forma de tabelas.

Estas tabelas, sendo auto-explicativas, encer ram em si mesmas as informações que permitem uma observação clara dos fenômenos ocorridos durante o experimento.

Não obstante sua aparente simplicidade, o pre sente experimento trouxe à $1 \mathrm{uz}$ da ciência, um conjunto de in formações úteis, que aplicados na ärea das atividades agronô micas, produzirão resultados positivos. 
.37 .

As tabelas que se seguem estão ordenadas em função dos objetivos deste experimento, obedecendo a mesma or. dem na qual foram apresentados na Introduça deste trabalho.

Na tabela 5 são apresentados os resultados re ferentes à altura média das plantas, em determinada fase do seu desenvolvimento (aos três meses de idade), em função dos diferentes tratamentos, ou seja, em função das diferentes fon tes, formas de aplicação e quantidade de Cálcio e de Enxofre aplicados no solo (para as duas variedades estudadas).

Na tabela 6 , se observa os resultados rela tivos às diferentes produções médias obtidas (em toneladas por hectare), de cana-de-açúcar, em função dos diferentes tratamen tos (diferentes fontes, formas de aplicação, e quantidade de Cá 1 cio e de Enxofre), para as duas variedades estudadas.

Na tabela 7, vê-se os teores médios de Cál cio e de Enxofre encontrados nas folhas de cana-de-açúcar (aos nove meses de idade), em função dos diferentes tratamentos, para a variedade NA-5679.

Na tabela 8, vê-se os resultados análogos aos da tabela anterior, porém, para a variedade $\mathrm{CB}-4176$.

Na tabela 9, observam-se os teores médios de $N, P, K$ e $M g$ encontrados nas folhas (aos nove meses de ida- 
.38 .

de), em função das quantidades em que os mesmos foram aplicados ao solo, em todos os tratamentos, para a variedade NA-5679.

Na tabela 10 , observam-se os resultados anā logos aos da tabela anterior, porém, para a variedade CB -4176 .

Na tabela 11, são apresentados os resultados relativos aos teores médios de Cálcio e de Enxofre encontrados nas folhas (aos nove meses de idade), correspondentes às respeç tivas produções médias obtidas (na mesma ocasião), para a varie dade NA-5679.

Finalmente a tabela 12 , apresenta resultados anălogos aos da tabela anterịor, porém, para a outra variedade estudada, a CB-4176.

Os resultados apresentados nas tabelas, foram devidamente colocados em respectivos gräficos, a fim de poderem ser visualizados e discutidos com a maior clareza e objetividade possiveis.

Após cada tabela (ou grupo de tabelas), se guem os gráficos respectivos procurando dar uma idéia clara e simples dos fenômenos ocorridos.

Após a apresentação das tabelas, e dos respeç tivos gräficos, segue uma sequência de fotos, (de alguns trata mentos), onde aparece o autor do presente trabalho. 
Antes da sequēncia de tabelas e gräficos, apresentada a seguir, a anälise estatistica dos dados de produção média por hectare.

\section{Anälise Estatística}

Os quadros apresentados a seguir mostram os va lores obtidos na produção (toneladas/hectare) para as duas va riedades de cana-de-açúcar estudadas.

QUADRO 3 . Valores obtidos em cada uma das quatro repetições, e a média para cada tratamento (t/ha). Varieda de NA-5679.

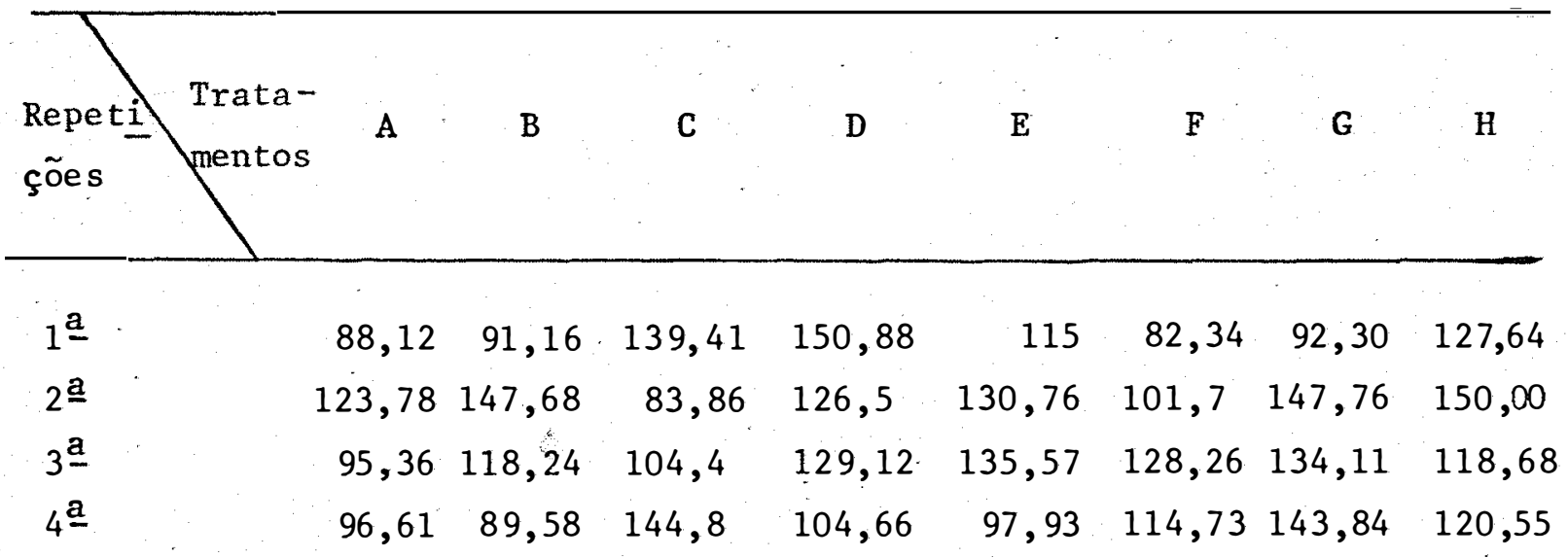

Média

$93,36 \quad 111,66 \quad 129,53 \quad 127,79 \quad 119,81 \quad 114,89 \quad 141,90 \quad 122,29$




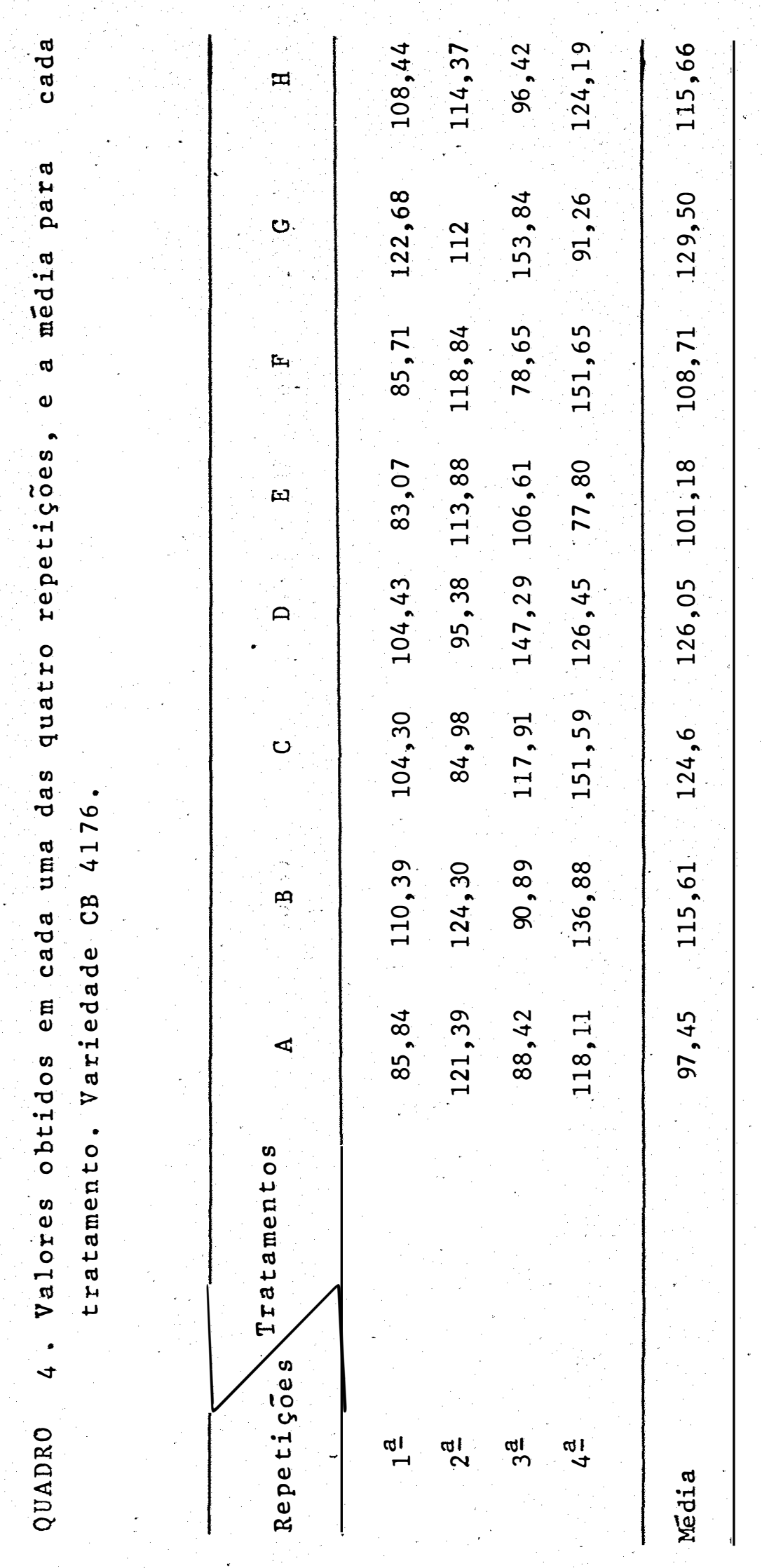


Para a variedade NA-5679, montou-se, a partir destes valores obtidos, o quadro apresentado a seguir.

QUADRO 5. Totais de linhas e totais de colunas para a varie dades NA- 5679 .

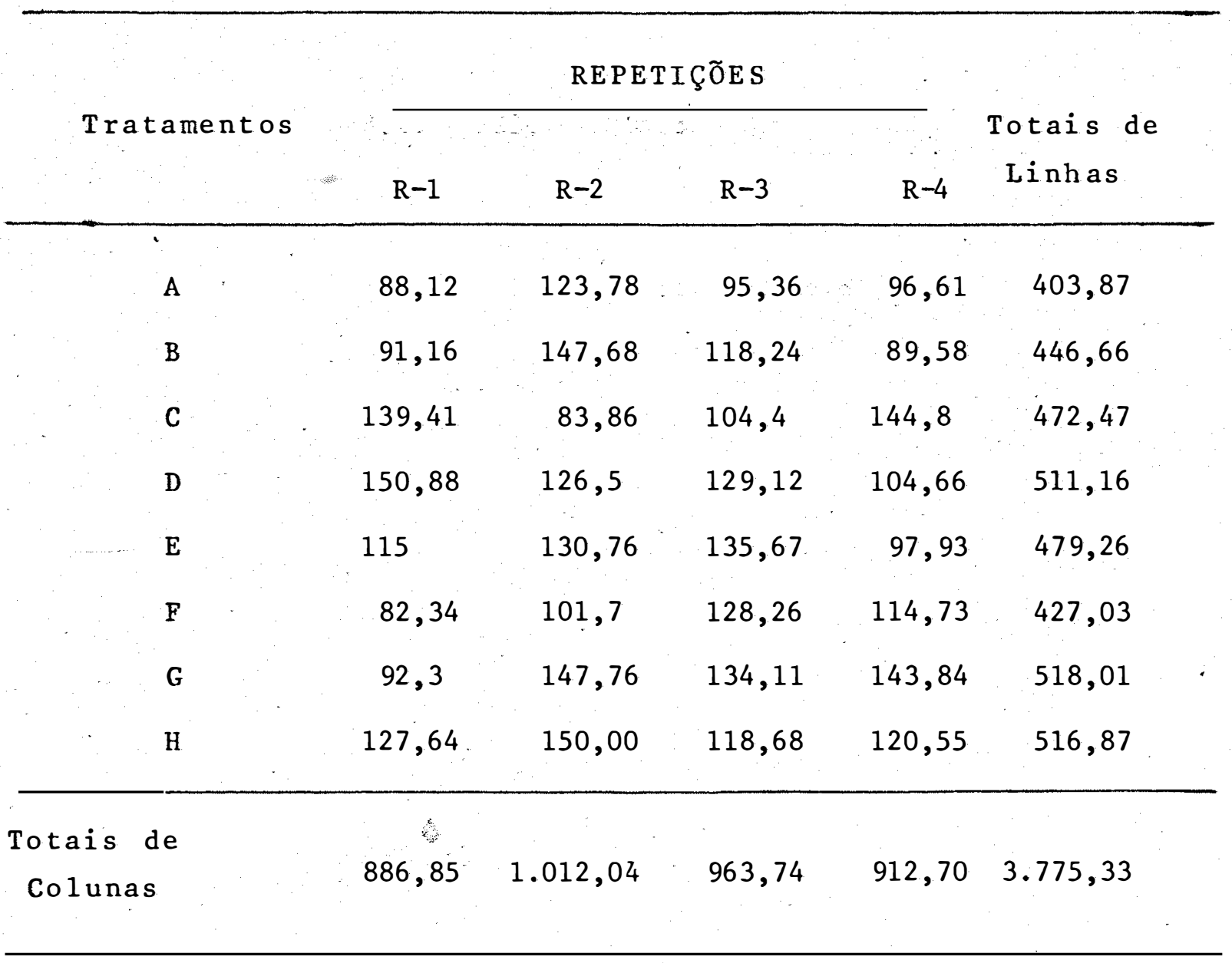


Teve-se, então, a seguinte análise de variân cia :

QUADRO 6. Anāilse de variância para a variedade NA-5679 $\because$

\begin{tabular}{ccccc}
\hline $\begin{array}{c}\text { Causa de } \\
\text { Variação }\end{array}$ & G.L & S.Q. & Q.M. & F \\
\hline Blocos & 3 & $1.158,105$ & 386,03 & 0,810 \\
Tratamentos & 7 & $3.255,68$ & 465,09 & $0,976 * *$ \\
Residuos & 21 & $10.007,54$ & 476,55 & \\
\hline
\end{tabular}

Tota 1

$31 \quad 14.42,33$

Peloquadro, observa-se que o valor de F para blocos é igual a 0,810, com 3 e 21 graus de 1 iberdade. Este resultado obtido para blocos $(0,810)$, segundo PIMENTEL GOMES (1973) não é significativo, pois não atinge o limite de $5 \%$ de probabilidade (que seria igual a 3,07 ).

Por este mesmo quadro, pode-se observar que o valor de F para tratamentos é igual a 0,976 com 7 e 21 graus de 1 iberdade. Este resultado obtido para tratamentos $(0,976)$ ainda conforme PIMENTEL GOMES (1973) é significativo ao ni vel de $1 \%$ de probabilidade, o que se indica com dois asteris $\cos$ 
Ao nível de $5 \%$ de probabilidade para $F<1$, 0 válor obtido para tratamentos $(0,916)$ é também significativo.

Para outra variedade de cana-de-açúcar estuda da, a $C B-4176$, montou-se a partir dos valores obtidos (ton/) ha); o quadro apresentado a seguir:

QUADRO 7. Totais de linhas e totais de colunas para a varie dade $C B-4176$.

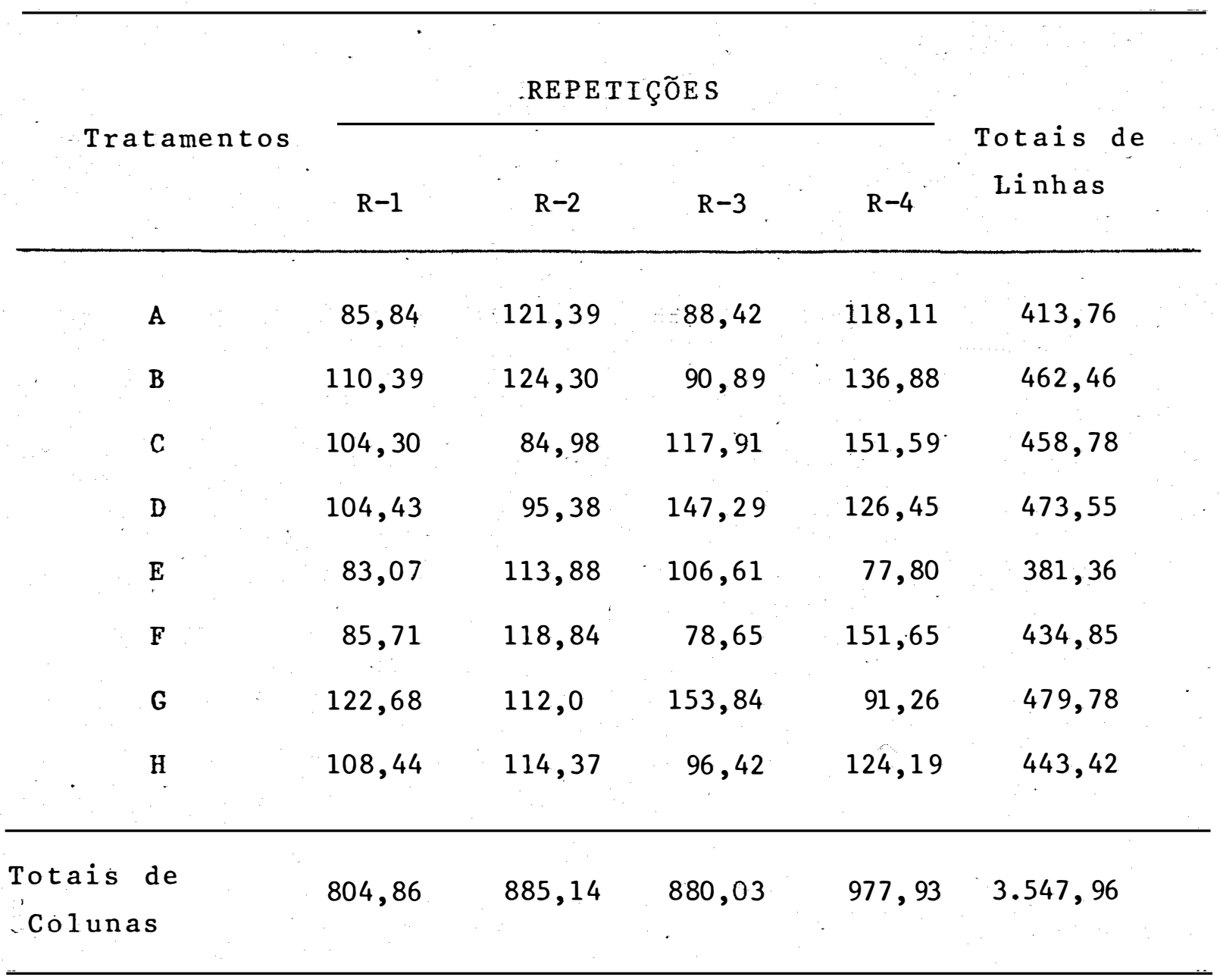


Teve-se então a seguinte anāilse de variância:

QUADRO 8 . Anālise de variância para a variedade $C B-4176$.

Causa de
Variação

\begin{tabular}{ccccc} 
Blocos & 3 & $1.883,41$ & 627,80 & 1,188 \\
Tratamentos & 7 & $1.908,22$ & 272,60 & $0,516^{* *}$ \\
Residuos & 21 & $11.097,44$ & 528,45 & \\
\hline Total & 31 & $14.889,07$ & \\
\hline
\end{tabular}

Pelo quadro, observa-se que o valor de F para blocos é igual a $1,188, \operatorname{com} 3$ e 21 graus de 1 iberdade. Este resultado obtido para blocos (1,188), segundo PIMENTEL GOMES (1973) não é significativo, pois não atinge o limite de $5 \%$ de probabilidade $(3,07)$.

Ainda neste mesmo quadro, pode-se observar que o valor de F para tratamentos è igual a 0,516 com 7 e 21 graus de 1 iberdade. Este resultado obtido para tratamentos. $(0 ; 516)$ ainda conforme PIMENTEL GOMES (1973) é significativo, ao nível de $1 \%$ de probabilidade, o que se indica com dois as teriscos.

Ao nível de $5 \%$ de probabilidade para $F<1$, o valor obtido para tratamentos $(0,516)$ é também significativo. 
4.2. Tabela e Gräficos respectivos, relativos ao sub-capI tulo 5.1 .

TABEla 5. Altura média das plantas de cana-de-açūcar (aos três meses de idade) em função das diferentes fon tes, formas de aplicação, e respectivas quantida des de Cálcio e de Enxofre fornecidas ao solo. (pa ra as duas variedades estudadas).

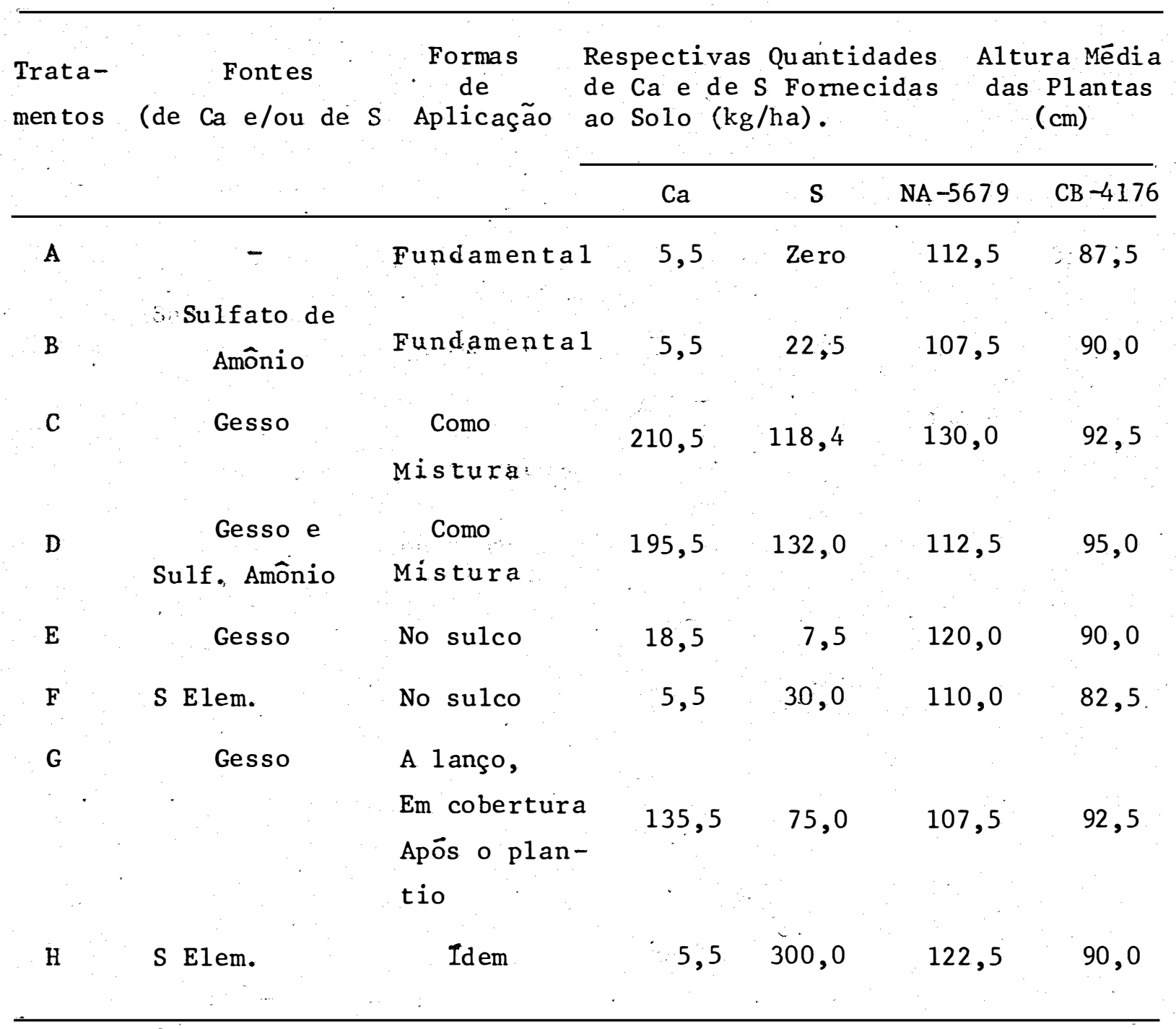




\section{0}

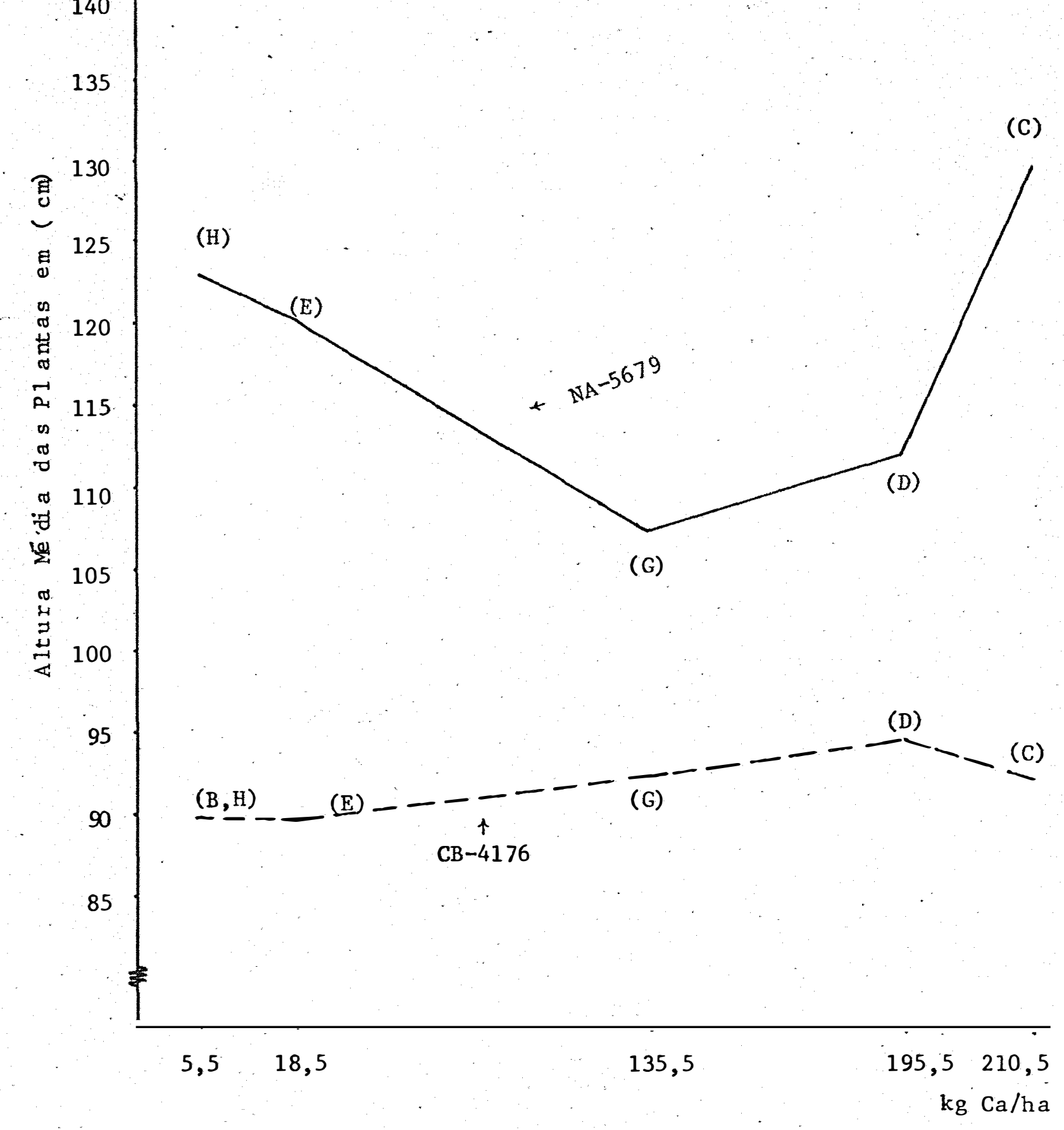

Figura 1. Altura média das plantas de cana-de-açücar (aos três me ses de idade), em função das diferentes fontes, formas de aplicação e respectivas quantidades de Cálcio aplicadas ao solo (para as duas variedades estudadas). As letras en treparênteses se referem aos tratamentos. 


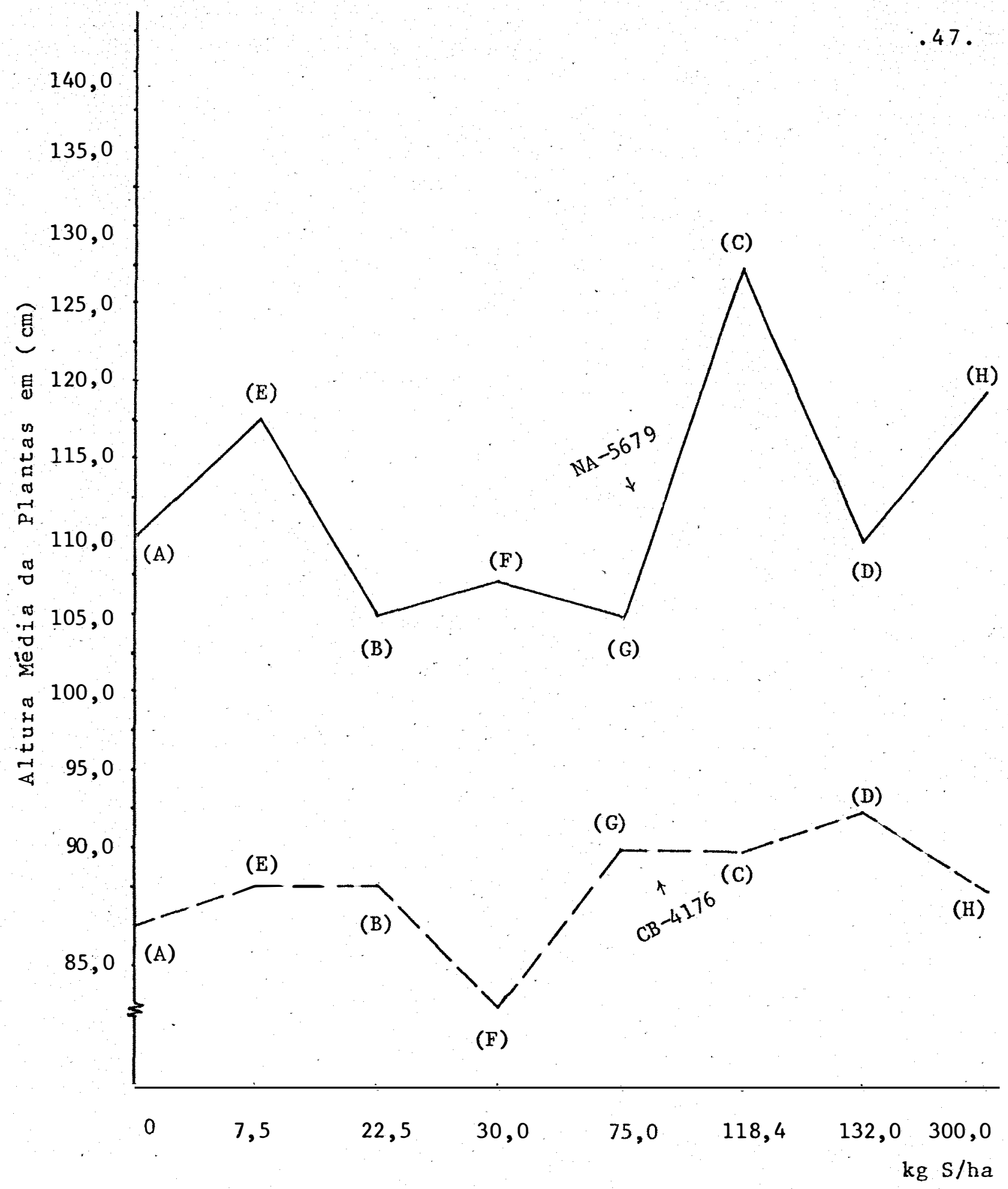

Figura 2 . Altura média das plantas de cana-de-açúcar (aos três me ses de idade), em função das diferentes fontes, formas de aplicação e respectivas quantidades de Enxofre ap1i cadas ao solo (para as duas variedades estudadas). As le. tras entreparênteses se referem aos tratamentos. 
4.3. Tabela e Gräfico respectivos, referentes ao sub-capí tulo 5.2 .

TABELA 6. Produções médias de cana-de-açūcar (aos nove meses de idade) em função das diferentes fontes, formas de aplicação e respectivas quantidades de cálcio e de Enxofre fornecidas ao solo (para as duas varieda des estudadas ).

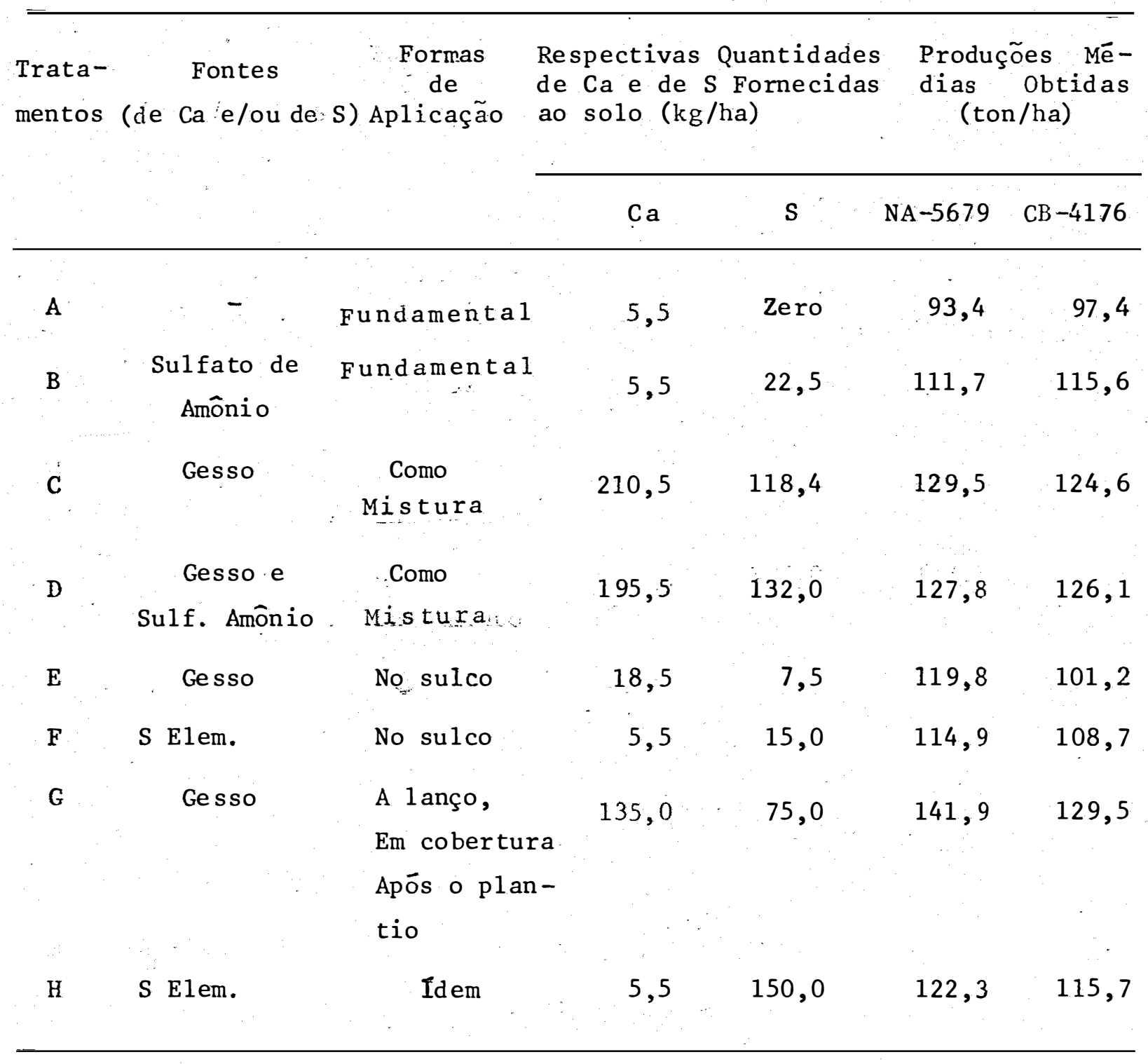




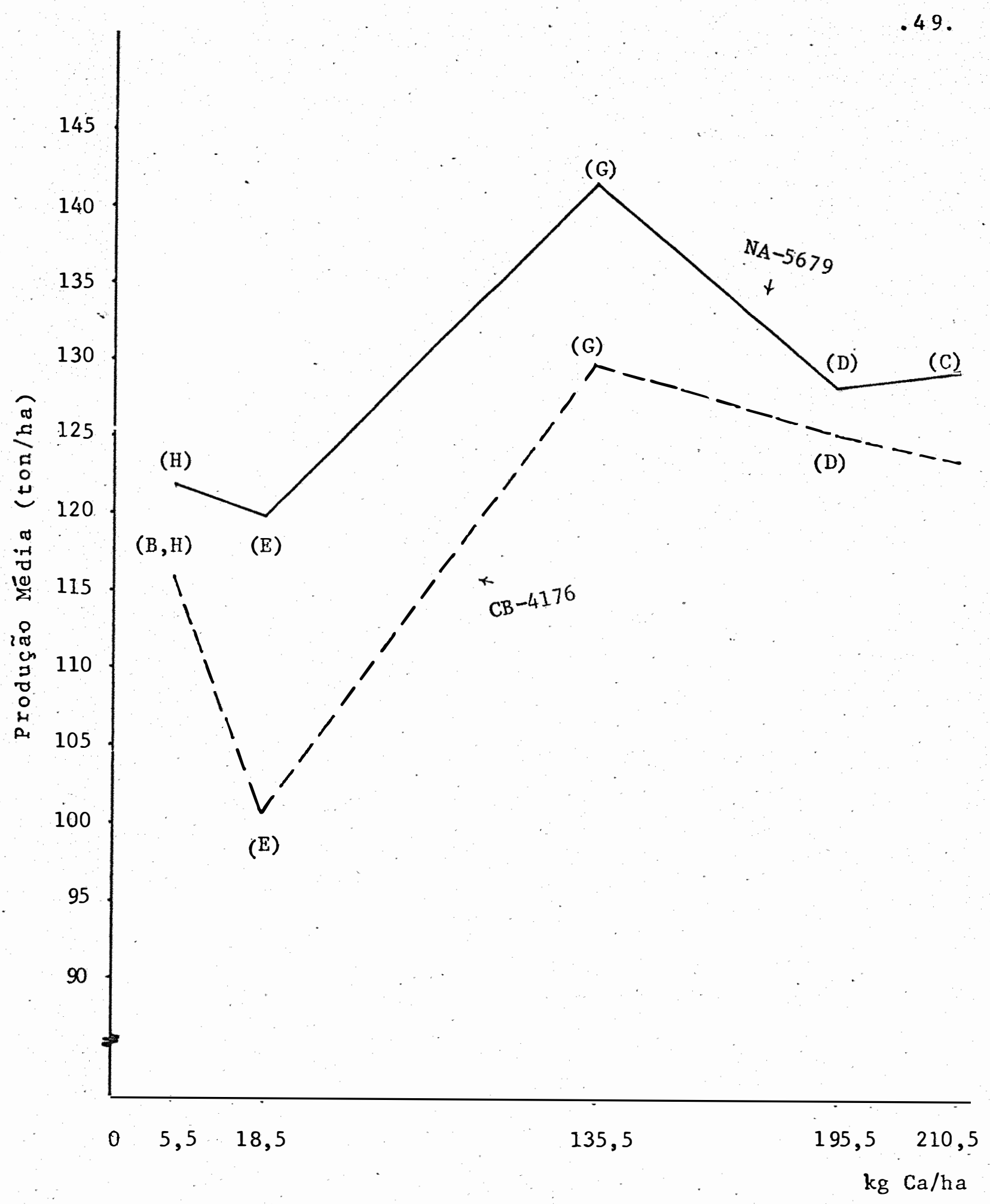

Figura 3 . Produção mêdia de cana-de-açúcar (aos nove meses de ida de), em função das diferentes fontes, formas de aplica ção e respectivas quantidades de Cálcio aplicadas ao so 10 (para as duas variedades estudadas). As letras entreparênteses, se referem aos tratamentos. 


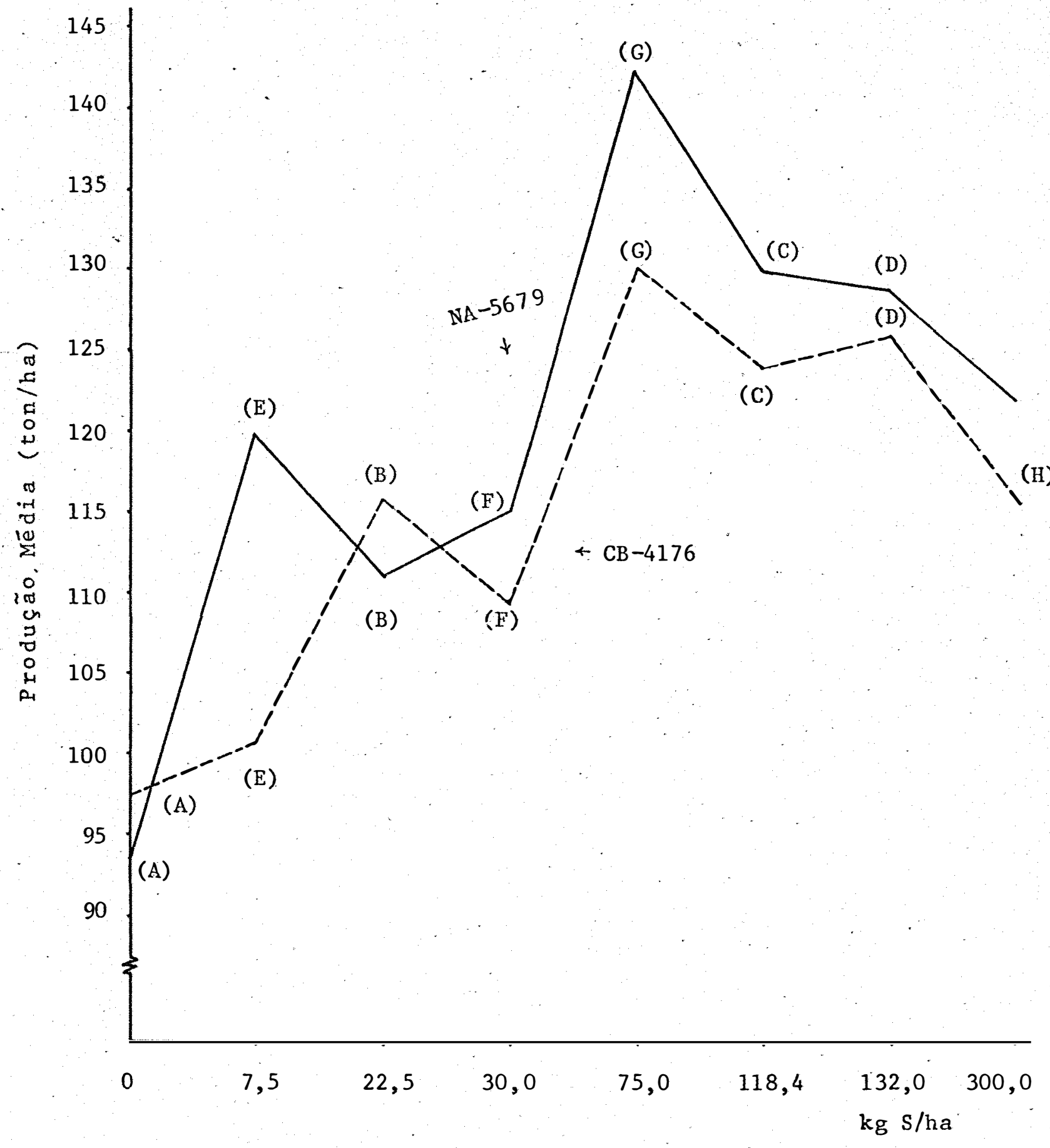

Figura 4. Produção média de cana-de-açūcar (aos nove meses de ida de), em função de diferentes fontes, formas de aplicação e respectivas quantidades de Enxofre aplicadas ao solo (para as duas variedades estudadas). As letras entrepa rênteses se referem aos tratamentos. 
4.4. Tabelas e respectivos Gräficos referentes ao sub-capí tulio 5.3 .

TABELA 7. Teores médios de Cälcio e de Enxofre encontrados nas folhas de cana-de-açūcar (aos nove meses de idade), em função das diferentes fontes, formas de aplicação e quantidades em que foram aplicados ao solo. Variedade NA-5679.

\begin{tabular}{|c|c|c|c|c|c|c|c|c|}
\hline \multirow[b]{2}{*}{$\begin{array}{l}\text { Trata- } \\
\text { mentos }\end{array}$} & \multirow[b]{2}{*}{$\begin{array}{c}\text { Fontes } \\
\text { (de } \mathrm{Ca} \mathrm{e/ou} \text { ) } \\
\text { de S }\end{array}$} & \multirow{2}{*}{$\begin{array}{c}\text { Formas } \\
\text { de } \\
\text { Aplicação }\end{array}$} & \multicolumn{3}{|c|}{$\mathrm{Ca}$} & \multicolumn{3}{|c|}{$S$} \\
\hline & & & $\begin{array}{c}\text { No Solo } \\
\mathrm{kg} / \mathrm{ha}\end{array}$ & Nas & $\begin{array}{l}\text { Folhas } \\
\%\end{array}$ & $\begin{array}{l}\text { No Solo } \\
\mathrm{kg} / \mathrm{ha}\end{array}$ & Nas & $\begin{array}{l}\text { Folhas } \\
7\end{array}$ \\
\hline A & - & Fundaruental & 5,5 & & 0,32 & Zero & & 0,11 \\
\hline B & $\begin{array}{l}\text { Sulfato de } \\
\text { Amônio }\end{array}$ & Fundamental & 5,5 & & 0,32 & 22,5 & & 0,03 \\
\hline C & Gesso & $\begin{array}{c}\text { Como } \\
\text { Mistura }\end{array}$ & 210,5 & & 0,31 & 118,4 & 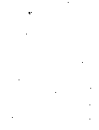 & 0,07 \\
\hline D & $\begin{array}{c}\text { Gesso e } \\
\text { Sulf:Amônio }\end{array}$ & $\begin{array}{c}\text { Como } \\
\text { Mistura }\end{array}$ & 195,5 & & 0,34 & 132,0 & & 0,09 \\
\hline$E$ & Gesso & No sulco & 18,5 & & 0,23 & 7,5 & & 0,08 \\
\hline $\mathrm{F}$ & S E 1 em: & No sulco & $.5,5$ & & 0,28 & 30,0 & & 0,08 \\
\hline$G$ & Gesso & A lanço, & & & & & - & \\
\hline & & $\begin{array}{l}\text { Em Cober- } \\
\text { tura, } \\
\text { Apōs plan } \\
\text { tio }\end{array}$ & 135,0 & & 0,30 & 75,0 & & 0,10 \\
\hline $\mathrm{H}$ & S Elem. & Id em & 5,5 & & 0,34 & 300,0 & & 0,08 \\
\hline
\end{tabular}


TABELA 8. Teores médios de Cálcio e de Enxofre encontrados nas folhas de cana-de-açúcar (aos nove meses de idade), em função das diferentes fontes, formas de aplicação e quantidades em que foram aplicados so so 10 . Variedade CB -4176 .

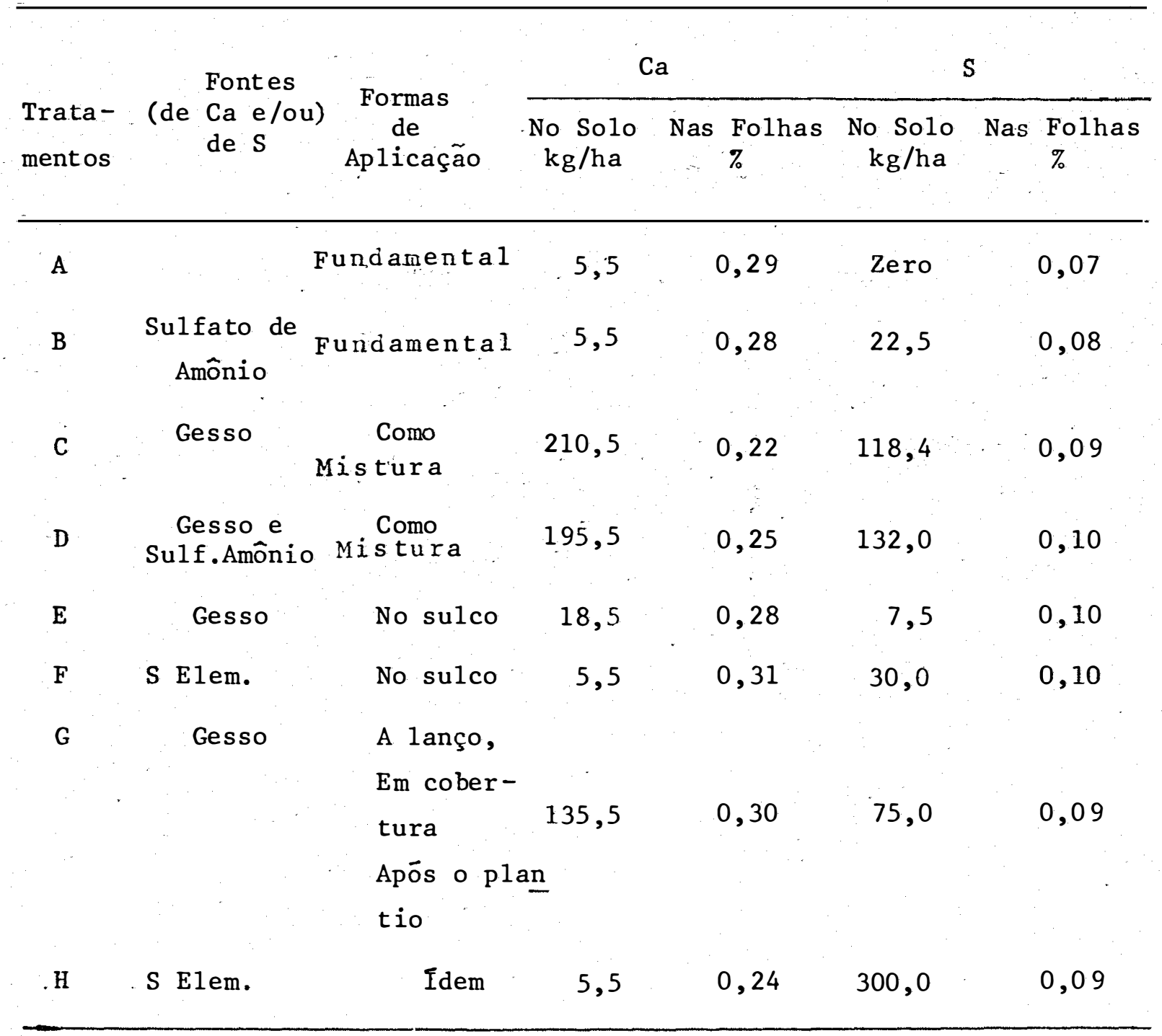




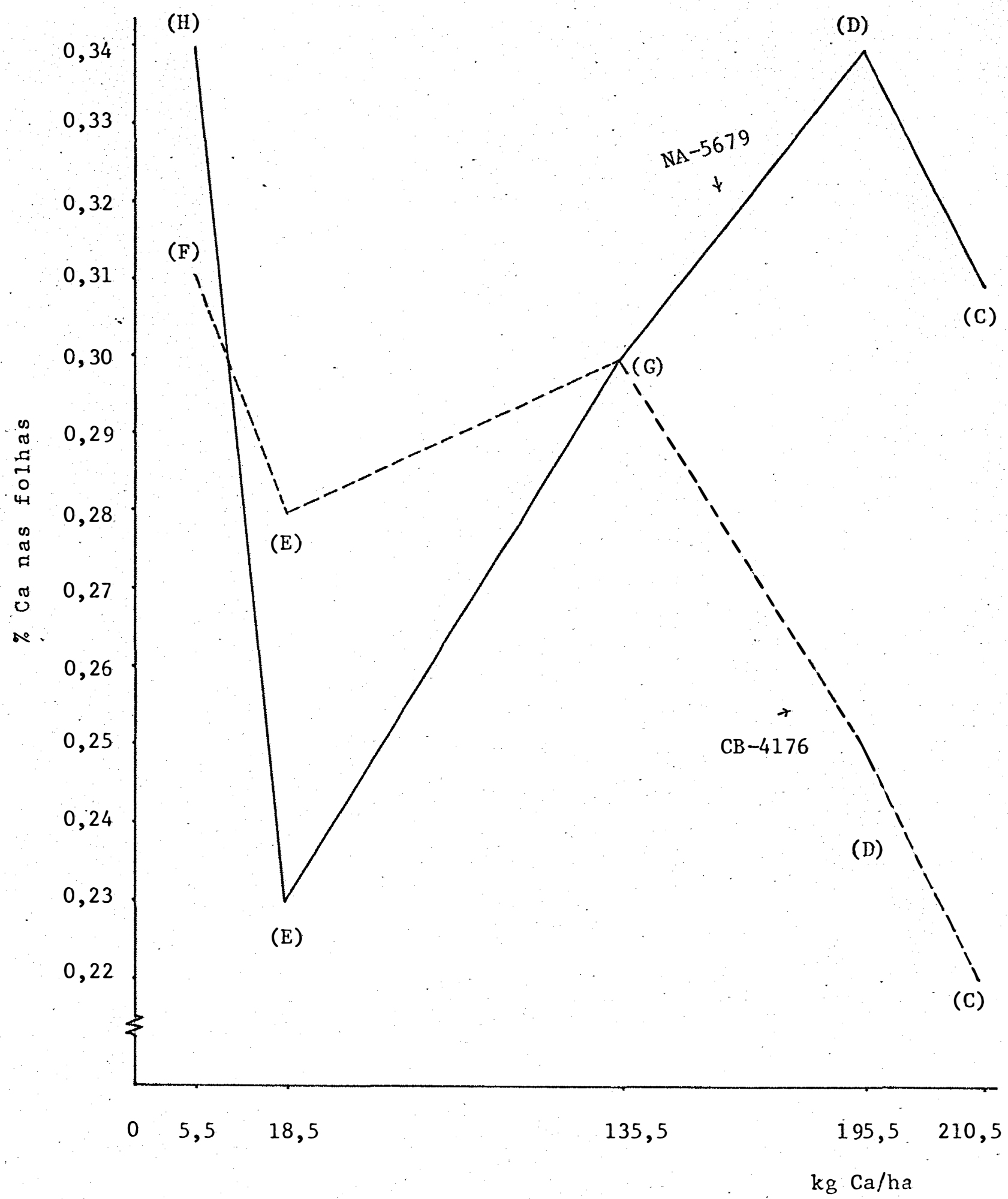

Figura 5. Teores médios de Cálcio nas folhas de cana-de-açúcàr (aos nove meses de idade), em função das diferentes fontes, formas de aplicação e respectivas quantidades em que foi aplicado ao solo (para as duas variedades estudadas). As letras entreparênteses se referem aos tratamentos. 


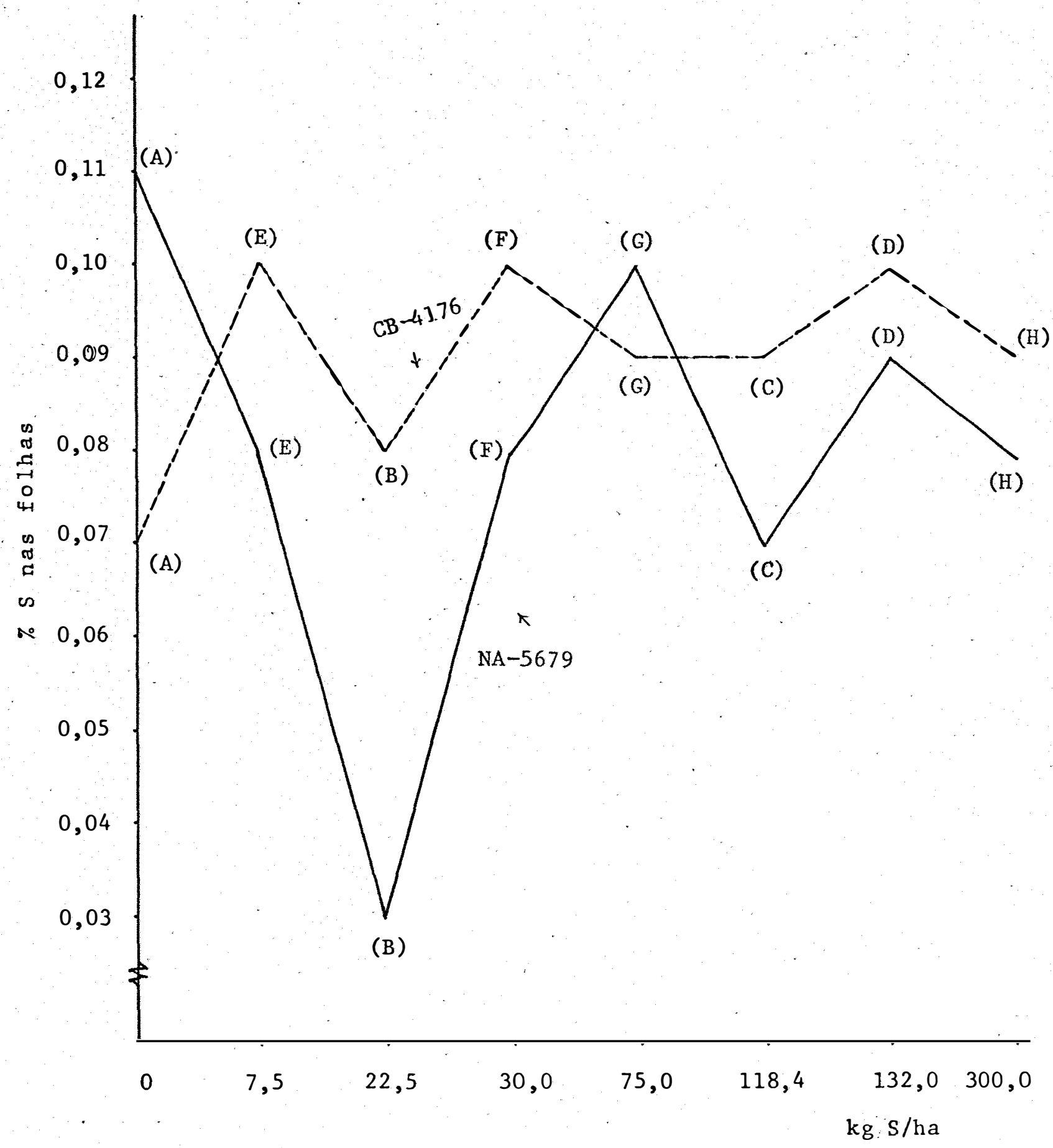

Figura 6. Teores médios de Enxofre nas folhas de cana-de-açücar (aos nove meses de id̆ade), em função das diferentes fon tes, formas de aplicação e respectivas quantidades em que foi aplicado a o solo (para as duas variedades estu dadas). As letras entreparênteses se referem aos trata mentos. 
.55 .

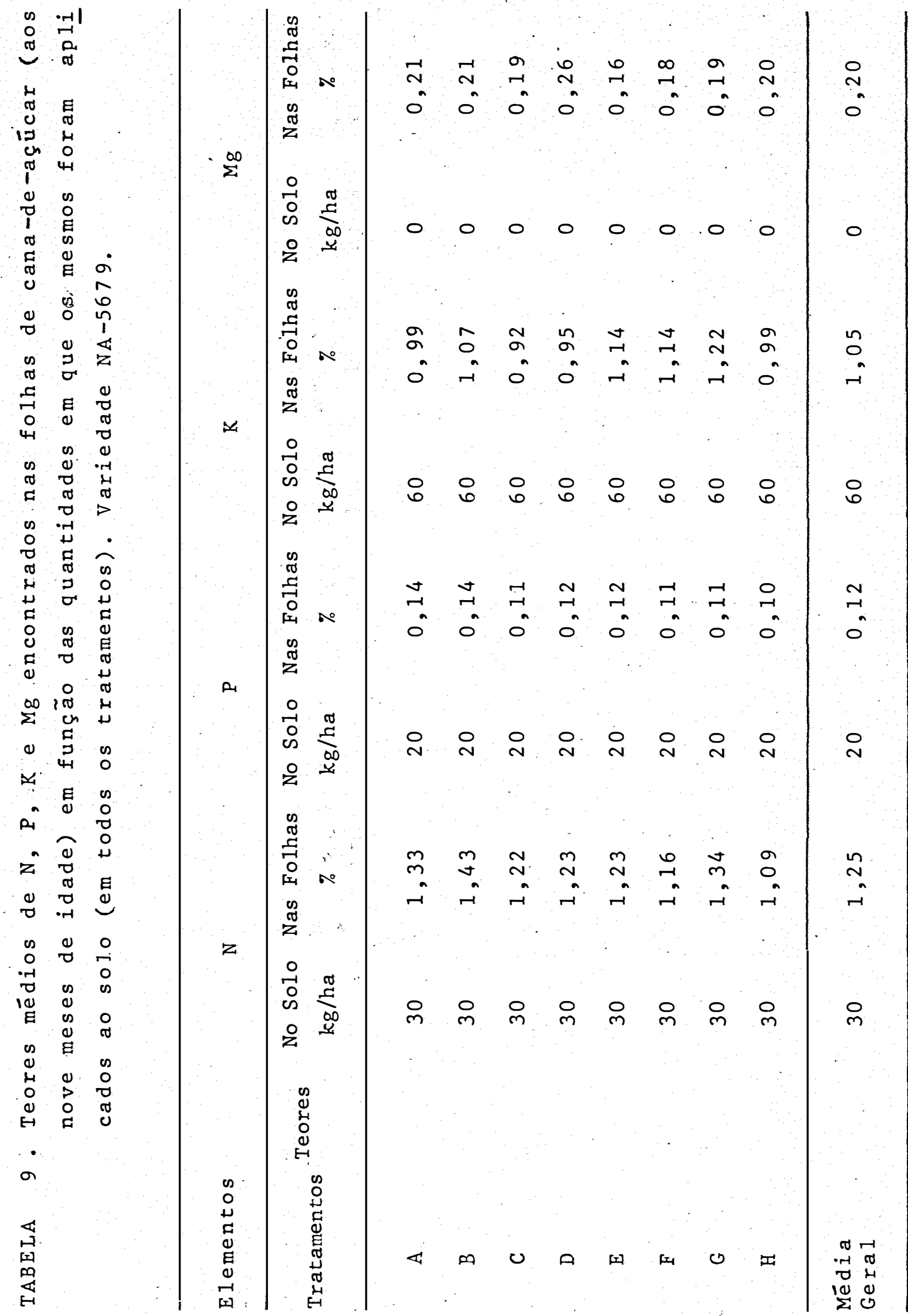


.56

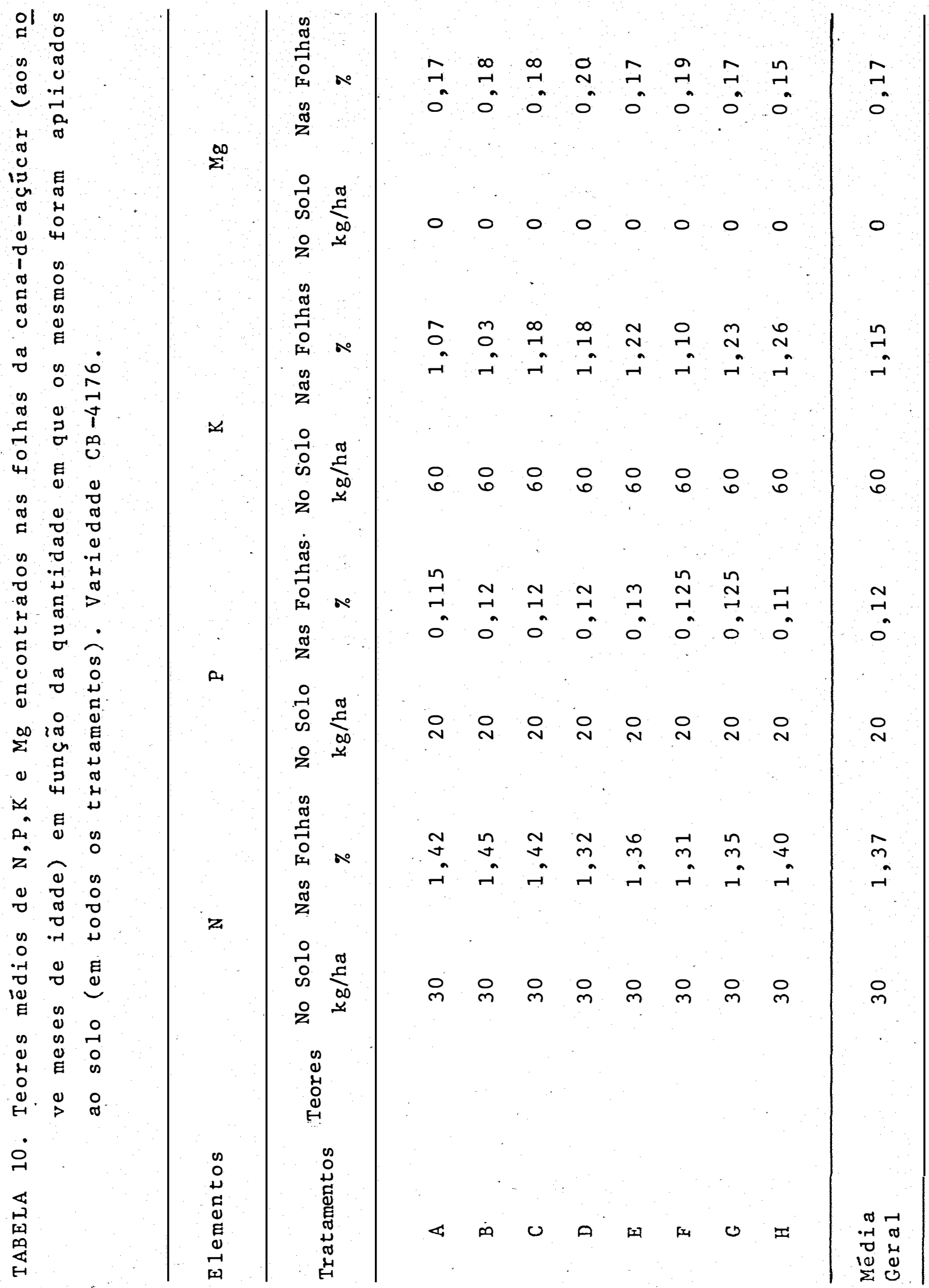




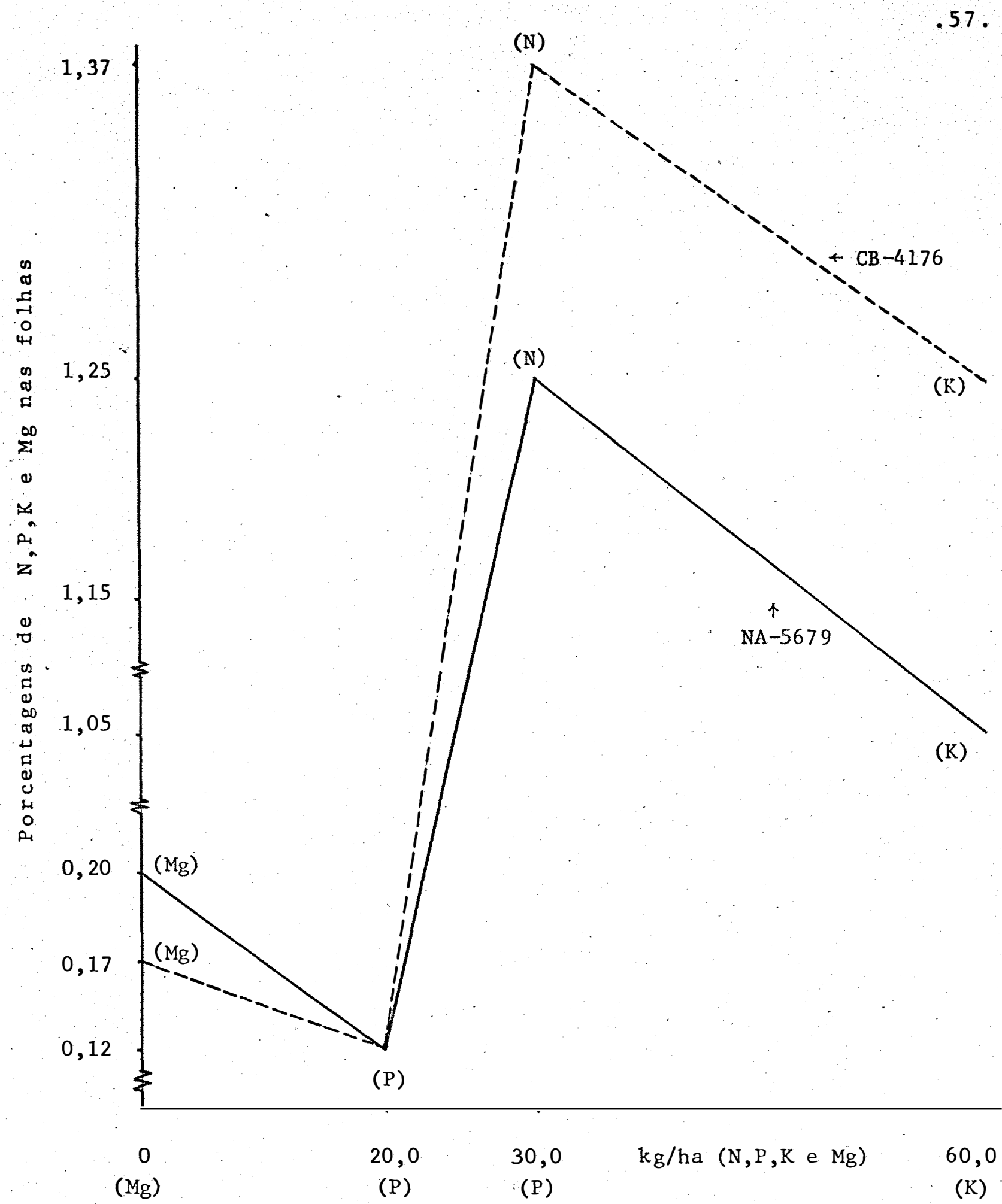

Figura 7. Teores foliares médios de $\mathrm{N}, \mathrm{P}, \mathrm{K}$ e $\mathrm{Mg}$ na cana-de-açūcar (aos nove meses de idade), em função das quantidades em que foram aplicados ao solo, em todos os tratamentos (para as duas variedades). 
.58 .

4.5. Tabelas e respectivos Gräficos, relativos ao sub-capÍ 105.4 .

TABELA 11. Teores médios de Cälcio e de Enxofre encontrados nạs folhas da cana-de-açūcar (aos nove meses de idade), e correspondentes produções médias verifi (na mesma ocasião). Variedade NA-5679.

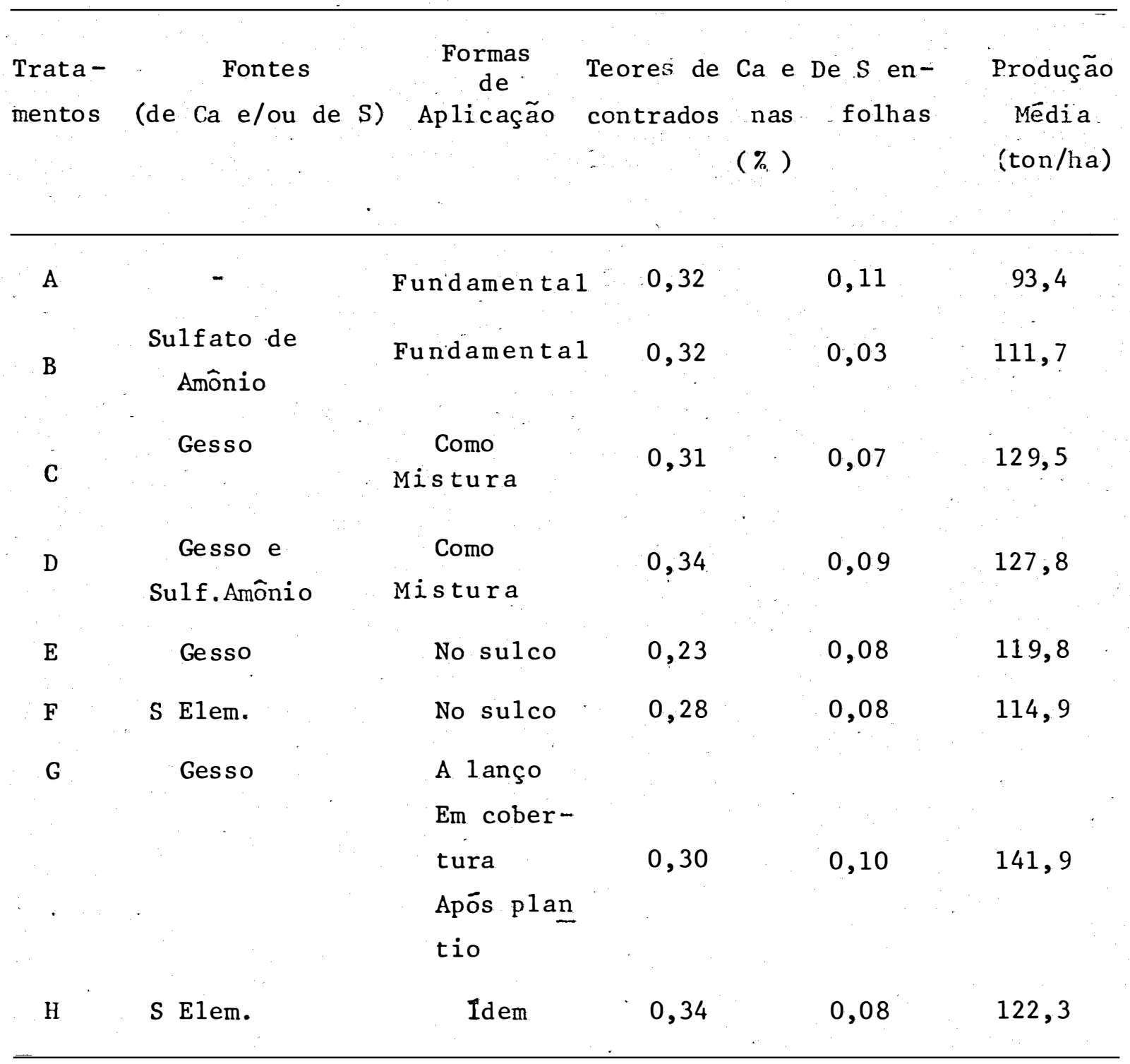


TABELA 12. Teores médios de Cālcio e de Enxofre encontrados nas folhas da cana-de-açúcar (aos nove meses de idade), e correspondentes produções médias verifi cadas (na mesma ocasião). Variedade $\mathrm{CB}-4176$.

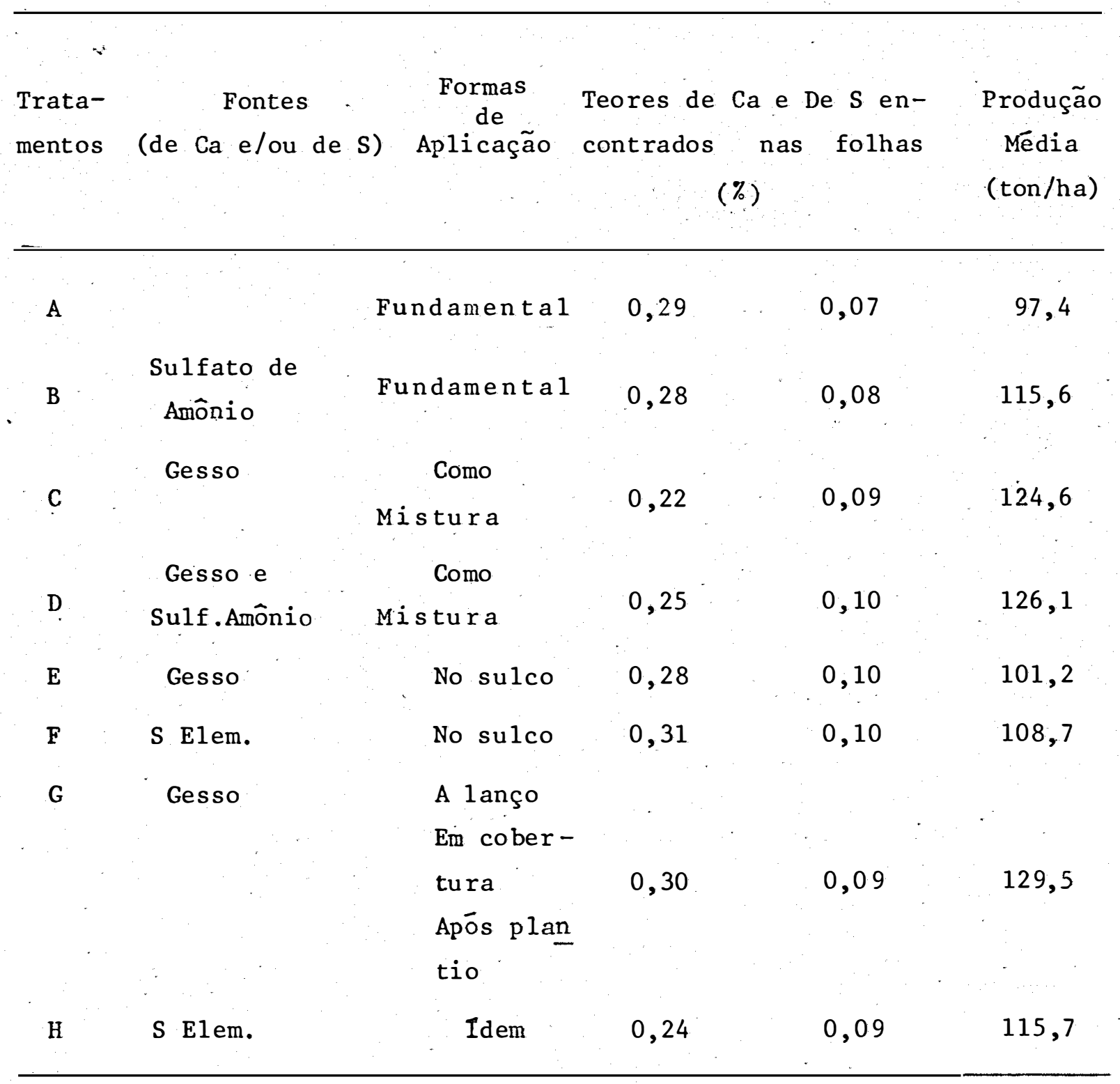


.60

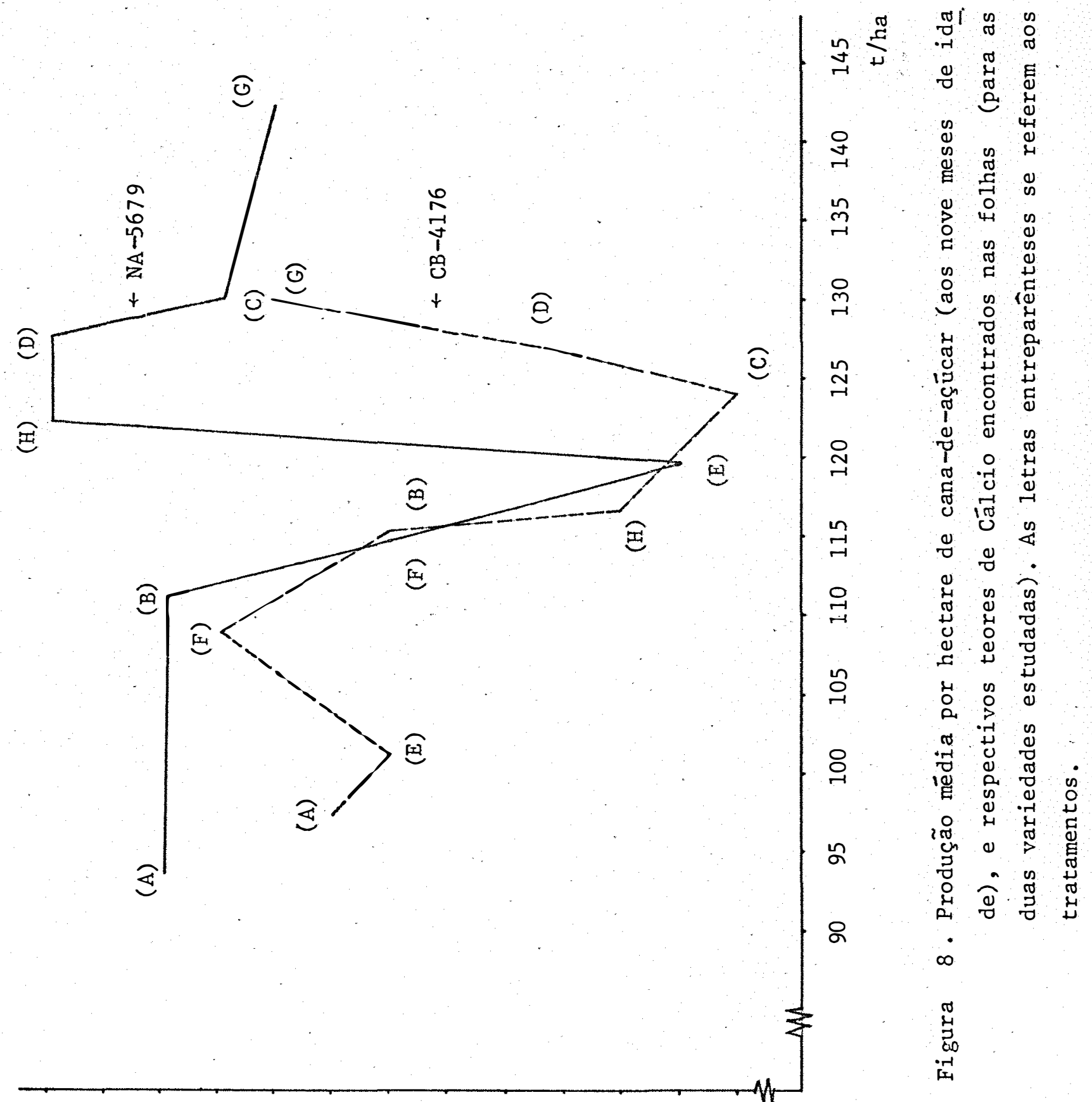

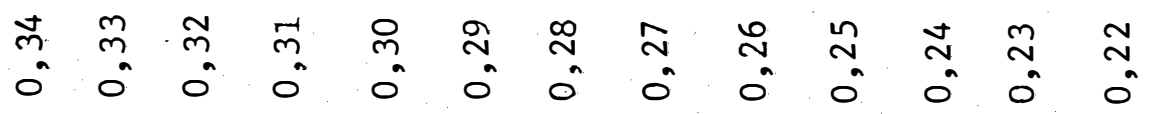

$$
\begin{aligned}
& \text { seylof seu eJ op \% }
\end{aligned}
$$




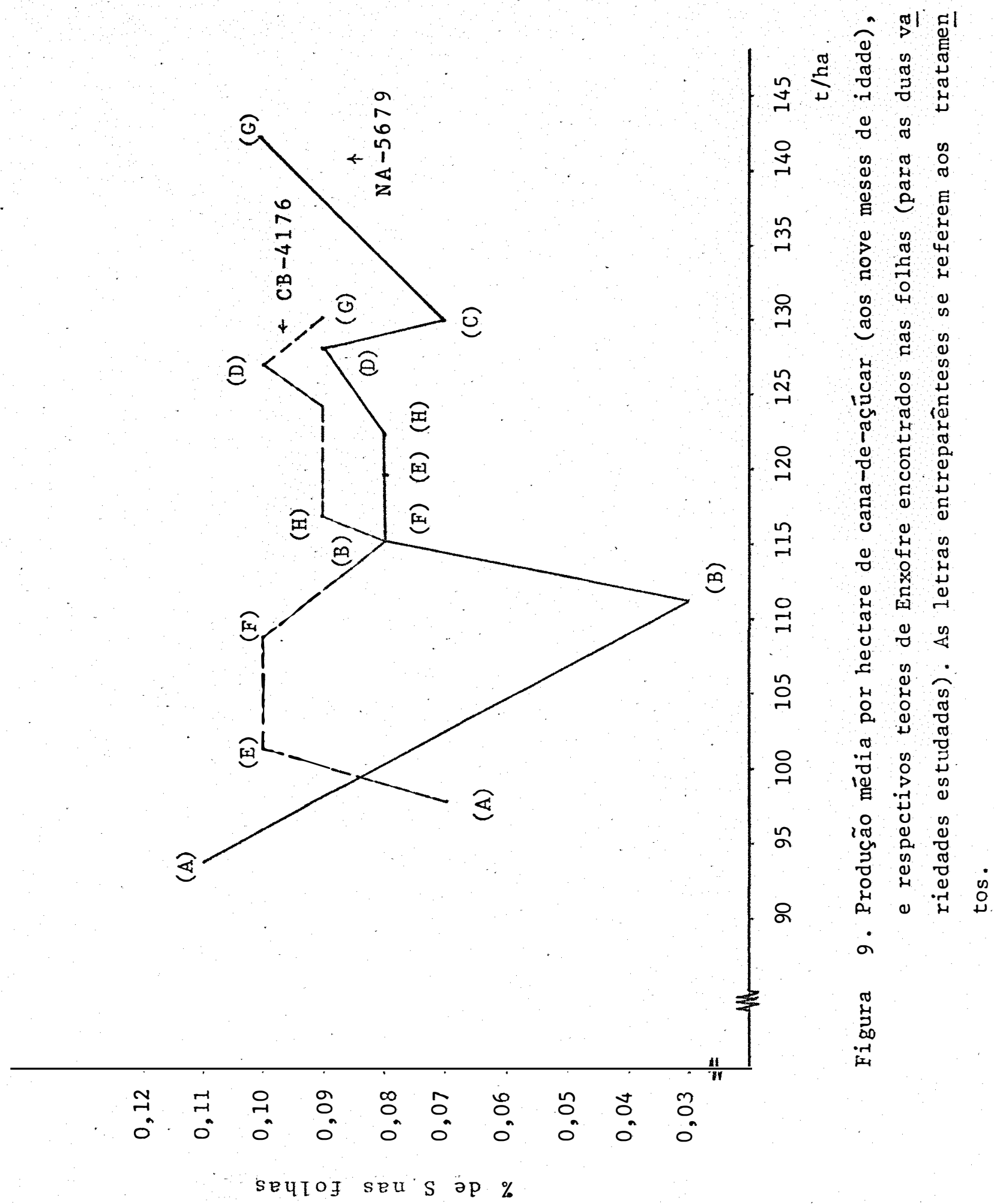


4.6. Fotos do Experimento

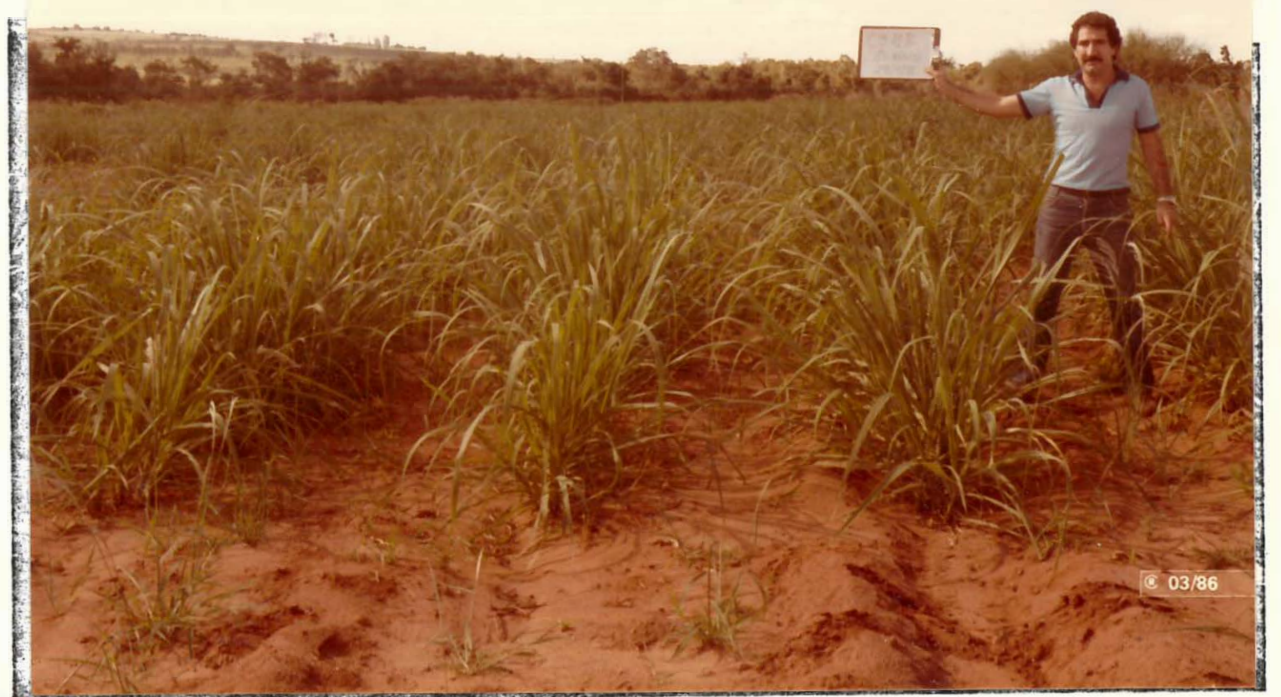

FIGURA 10 . Variedade $C B-4176$. Aspecto da cultura aos 3. (três) meses de idade. Gesso for necido como mistura (na fórmula de plantio), dose relativamente elevada: $790 \mathrm{~kg} / \mathrm{ha}$ ). 


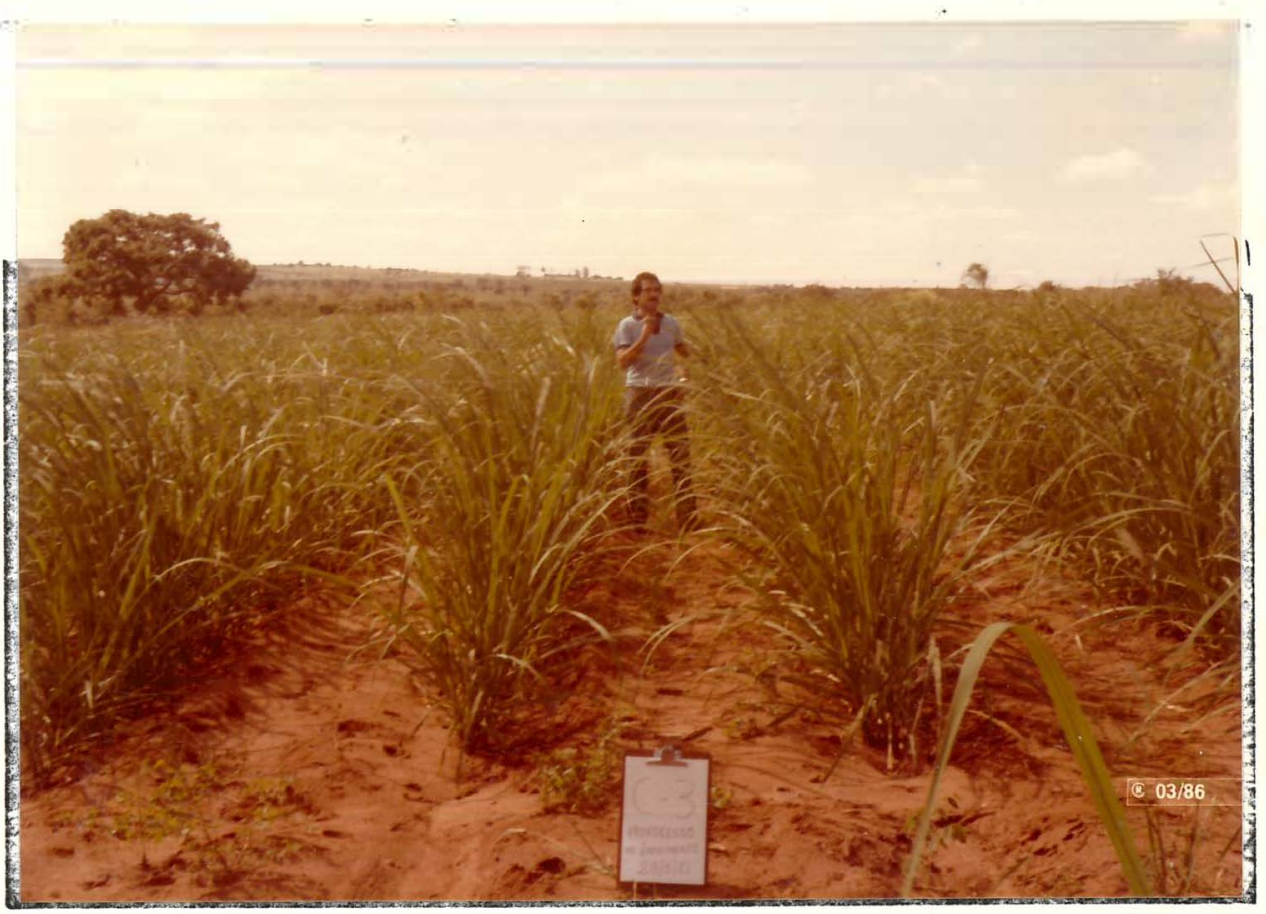

FIGURA 11. Variedade NA-5679. Aspecto da culturá aos 3 (trêss) meses de idade. Gesso for necido como mistura (dose relati vamente elevada: $790 \mathrm{~kg} / \mathrm{ha}$ ). 
.64.

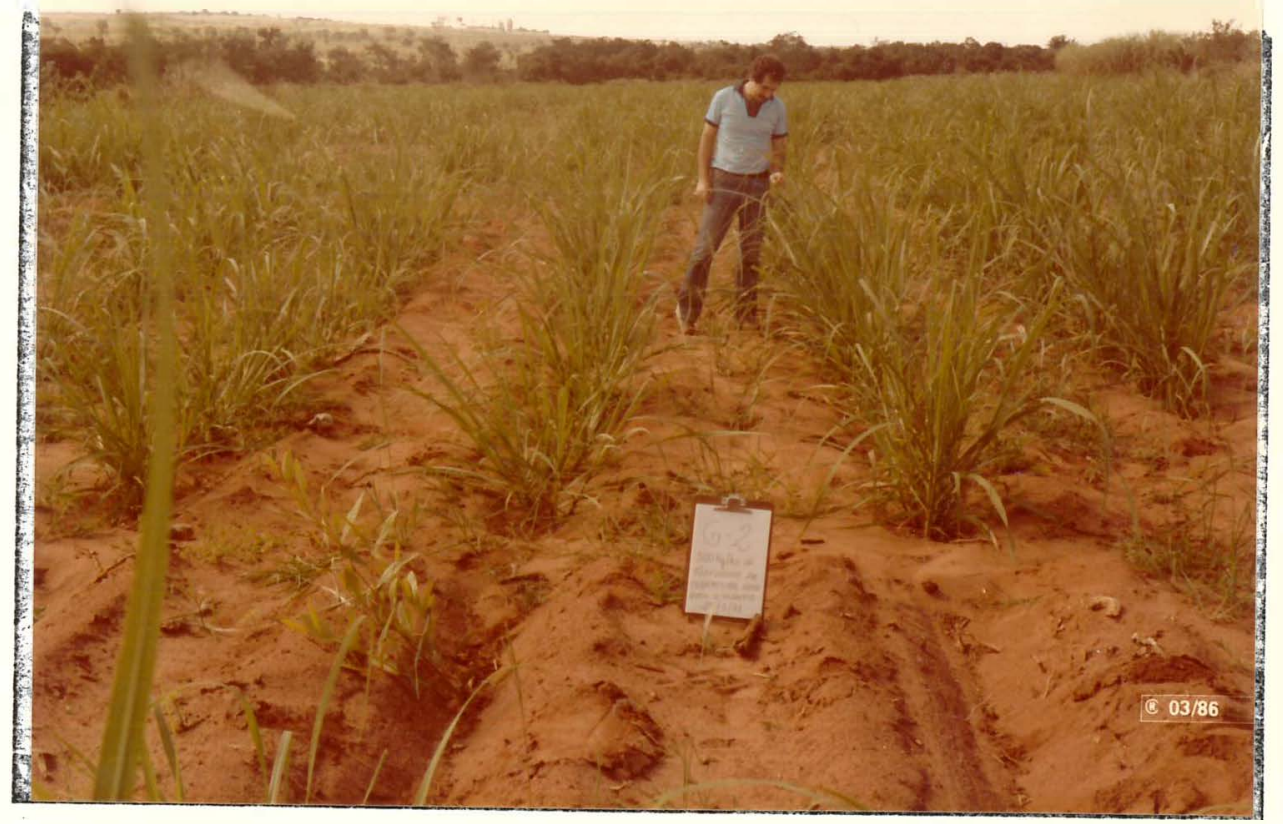

FIGURA 12. Variedade NA-5679. Tratamento G (repe tição 2). Na prancheta se 1 ê: "500 kg/ ha de Fosfogesso, em cobertura logo após o plantio". 
.65 .

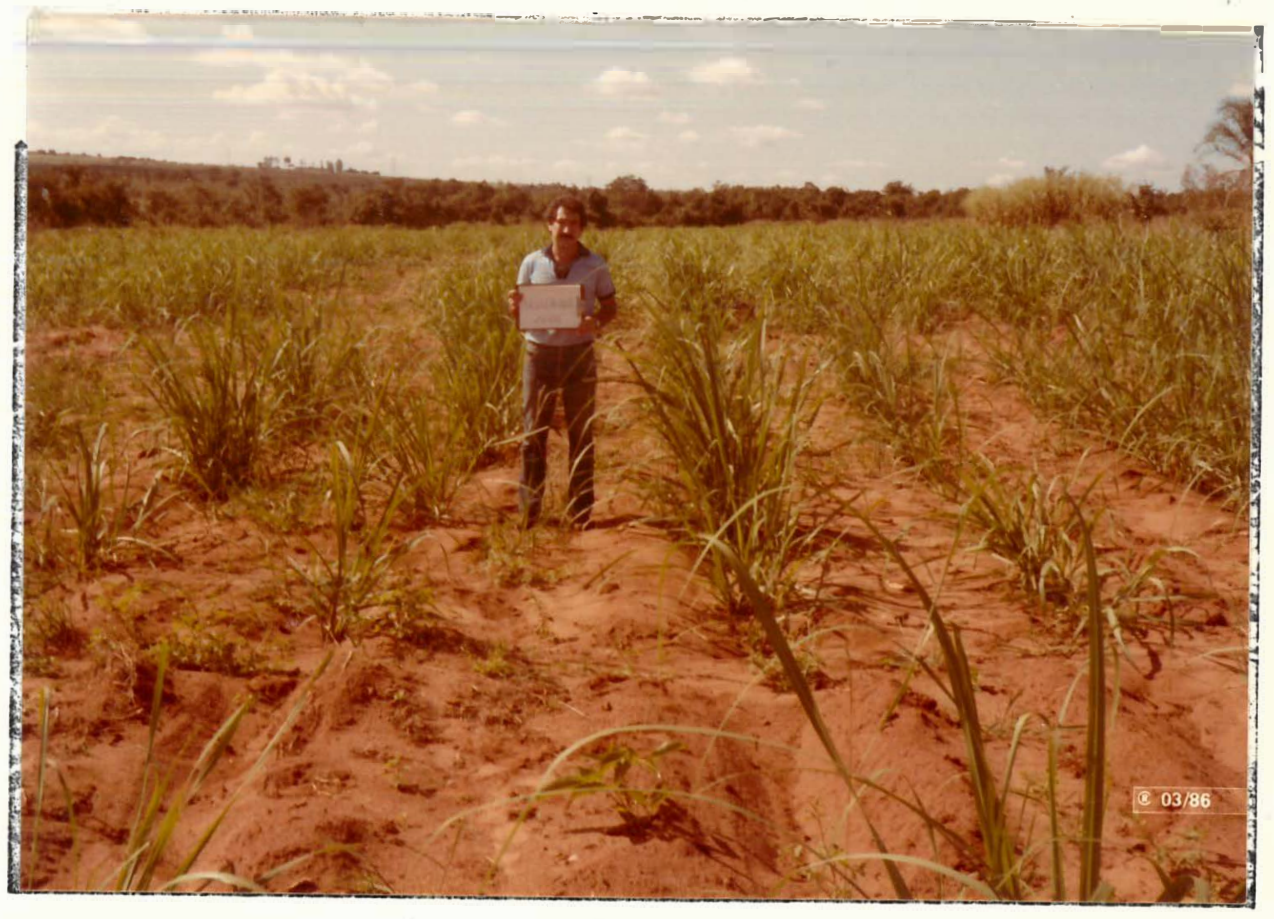

FIGURA 13. Variedade NA 56-79 (aos três meses). Testemunha total (sem adubação nem ges so). 


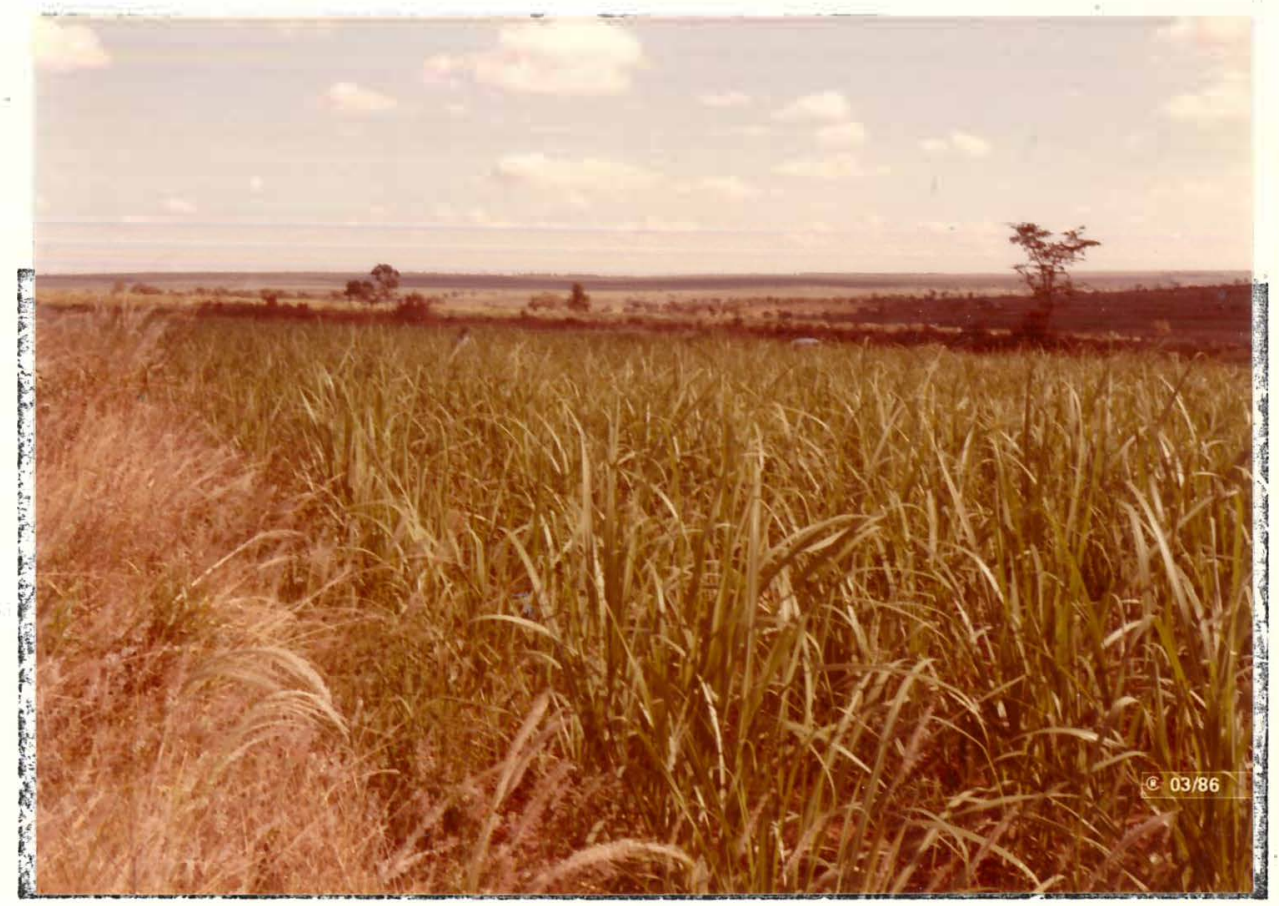

FIGURA 14. Vista geral do experimento, e do 1ocal onde foi instalado, na fazenda da Escola Superior de Agronomia de Para guaçú Paulista (Fazenda Modelo), no município de Paraguaçü Paulista-SP. 


\section{-5. DISCUSS $\AA 0$}

5.1. Relação entre a altura média das plantas laos noventa dias de idade) e os respectivos tratamentos aplicados

Nas duas variedades estudadas, a maior altura média das plantas (aos três meses de idade), foi observada nos tratamentos que receberam o gesso como mistura (corres pondentes as maiores doses de Cálcio e de Enxofre, ofereci das).

Para a variedade NA-5679, a menor a1tura mé dia das plantas (nesta fase do seu desenvolvimento) foi obser vada no tratamento que recebeu o gesso em cobertura após o plantio, o mesmo tendo sido constatado no tratamento que não 
recebeu gesso algum, cuja fonte de N foi o sulfato de amônio, aplicado no sulco.

- Para a outra variedade, a $C B-4176$, as menores plantas (nesta idade) foram verificadas no tratamento que re cebeu o enxofre na forma elementar aplicado no sulco, em do se relativamente pequena (sem cálcio, portanto). o tratamento que não recebeu cālcio nem Enxofre (testemunha) também prodü ziu plantas relativamente menores*.

Plantas relativamente altas também foram ob servadas na variedade $N A-5679$, no tratamento que recebeu enxo fre elementar em cobertura após o plantio, na dose relativa mente alta, o mesmo tendo acontecido em relaça ao tratamento que recebeu o gesso aplicado no sulco, em dose relativamente pequena.

0 mesmo não foi verificado nas plantas da va riedade $C B-4176$, onde estes mesmos tratamentos, nesta fase do desenvolvimento da cultura, mostraram efeitos que não se cor respondem inteiramente.

Estas diferenças podem ser explicadas pelo fa to de as duas variedades estudadas serem de naturezas diferen tes quanto à maturação, sendo uma precoce a (NA-5679) e a ou $\operatorname{tra}(C B-4176)$, tardia.

*NOTA. Na verdade, a ausência de Cálcio não foi absoluta, vis to que uma quantidade relativamente pequena deste elemento $(5,5 \mathrm{~kg} / \mathrm{ha})$, conti da no superfosfato triplo, foi fornecida indistintamente a cada um dos tratamentos. 
.69 .

5.2. Relação entre produção mēdia por hectare e as diferen tes fontes, formas de aplicação e quantidades de cál cio e de Enxofre aplicadas ao solo.

* As maiores produções foram observadas nos tra tamentos que receberam o gesso em dose relativamente alta, em cobertura, após o plantio (em ambas as variedades).

Logo a seguir (tambêm para ambas as varieda des), as maiores produções foram verificadas nos tratamentos que receberam o gesso na forma de mistura em doses relati vamente superiores às aplicadas a lanço em cobertura, após o plantio.

Estas observações conferem, de certo modo co mo proposto por JONES e RUCKMAN (1.966).

Produções intermediárias foram constatadas nos tratamentos que receberam o enxofre elementar em cobertu ra após o plantio, em dose relativamente alta, de acordo com ANDREIS ( 1.975$)$.

Nos tratamentos que não receberam gesso, onde foram variadas as fontes de Nitrogênio (Uréia e Sulfato de Amônio), as produções foram as menores observadas. Entretan to, no tratamento cuja fonte de $\mathrm{N}$ foi o sulfato de amônio, a produção observada foi ligeiramente maior (indicando a influ. 
ência do enxofre, fornecido pelo sulfato de amônio).

Os tratamentos que receberam doses relativa mente pequenas de gesso ou de enxofre elementar no sulco tam bém resultaram em produções relativamente menores de acordo com MELLO et alii (1974) e MALAVOLTA et alii (1979).

Estes resultados permitem, pelo menos a prin cípio, deduzir que é mais vantajoso se aplicar o gesso em co bertura após o plantio, do que como mistura observa-se tam bëm, que a aplicação de doses relativamente pequenas de gesso ou de enxofre elementar no sulco, embora não resultem na ma or produção, pọem talvez trazer alguma vantagem sob o a pecto econômico.

Talvez a razão pela qual o gesso aplicado em cobertura após o plantio (em dose relativamente alta) tenha resultado em produção média superior àquela na qual foi usado como misturat se deva ao fato de o solo utilizado ser bas tante arenoso (sujeito, portanto; à intensa lixiviação). En tende-se que, desta forma, o material colocado na superfície (gesso), tenha chegado à zona das raízes após algum tempo quando a cultura já estava um pouco desenvolvida) o mesmo não tendo acontecido com o gesso aplicado como instura no sulco de plantio, em dose relativamente maior.

Pode-se admitir a hipōtese de que, se o solo 
no qual se desenvolveu o presente experimento fosse argiloso, onde o processo de lixiviação é menos pronunciado, estes mes mos tratamentos tivessem resultado em efeitos inversos, com relação à produção média por hectare.

5.3. Relação entre o teor dos elementos encontrado na folha, e o teor destes mesmos elementos aplicado ao solo.

A discussão dos resultados neste sub capitü 1o, centralizou sua atenção sobre os dois nutrientes ofereci dos pelo gesso, ou seja, o cálcio e o Enxofre. Não obstante, fez-se também um estudo da relação entre as quantidades de $N$, $\mathrm{P}, \mathrm{K}$ e Mg fornecidas ao solo, e o teor destes mesmos elemen tos encontado na folha.

\subsubsection{Teores foliares de Cálcio}

Teores relativamente maiores de cálcio foram encontrados nas folhas das plantas da variedade NA-5679, cu jos tratamentos receberam o gesso na forma de mistura (do ses relativamente altas). o mesmo não aconteceu com a outra variedade, onde os teores foliares relativos a estes mesmos tratamentos foram relativamente inferiores.

Estes resultados, possivelmente decorrentes da influência varietal, encontram apoio nas pesquisas desen 
volvidas por ORLANDO FILHO (1978).

Teores relativamente maiores de Cálcio foram também encontrados (em ambas as variedades), nas folhas das plantas que receberam o gesso em cobertura após plantio (do ses relativamente altas de Cālcio e de Enxofre aplicadas ao solo).

Nos tratamentos que receberam somente enxofre elementar (a 1 anço em cobertura na NA-5679, e no fundo do sul co para a $(B-4176)$, os teores de Cálcio encontrados nas fo lhas de ambas as variedades, foram paradoxalmente os mais ele vados. Para a variedade $C B-4176$, entretanto, isto não aconte ceu em relação ao tratamento que recebeu apenas enxofre ele mentar (na dose relativamente maior, em cobertura), sendo que o teor de cálcio encontrado nas folhas, neste caso, foi rela tivamente pequeno, condizente portanto, com o esperado.

Teores relativamente menores de Cálcio, foram encontrados nas folhas das plantas, cujos tratamentos recebe ram o gesso nas menores doses, aplicado no fundo do sulco (nas duas variedades), tendo sidomais pronunciado, porém, na va riedade $\mathrm{NA}-5679$.

Estes resultados sugerem a existência de pos síveis interações entre elementos aplicados juntos ou separa damente ao solo, bem como diferenças de comportamento entre 
variedades distintas.

\subsubsection{Teores foliares de Enxofre}

$\because \quad 0$ teor mais elevado de Enxofre, encontrado nas folhas da variedade NA-5679. (nesta fase de seu desenvolvimen to), correspondeu justamente ao tratamento que não recebeu en xofre algum. 0 menor teor foliar de Enxofre, nesta mesma va riedade, ocorreu no tratamento cuja üica fonte de $N$ e de $S$ foi o sulfato de amônio, dose relativamente pequena de enxo fre aplicada ao solo, portanto.

Nas duas variedades estudadas, observou-se teores relativamente altos de Enxofre, no tratamento que rece beu o gesso em cobertura (a lanço, após o plantio), dose rela tivamente alta, aplicada ao solo.

os tratamentos que receberam o gesso na forma de mistura, tambēm revelaram teores relativamente maiores de Enxofre nas folhas. De modo geral, os teores foliares de Enxofre foram relativamente elevados, com ligeiras variações. Tais variações, entretanto, não devem ser devidas à diférença varietal, uma vez que ambas as curvas obedeceram a um mesmo padrão gera1.

Nos dois tratamentos, nos quais um deles rece beu enxofre elementar em dose relativamente pequena aplicada. 
.74 .

ao sulco, e o outro recebeu gesso, também em dose relativamen te pequena aplicada ao sulco, os teores foliares de Enxofre correspondentes, foram equivalentes para cada uma das duas va riedades estudadas. Este fato revela, a princípio, que não houve qualquer influência por parte do cālcio sobre a absor §ão do enxofre, uma vez que o teor foliar deste elemento foi equivalente em ambos os tratamentos.

\section{$5.3 \cdot 3$. Teores foliares de $N, P, K$ e $M g$}

os teores destes elementos, detectados nas fo 1has, obedeceram fielmente, curvas bastante semelhantes para as duas variedades estudadas.

\section{Estes a}

Estes elementos em si, não constituíram o ob jeto principal do presente estudo, não deixando, entretanto, de ser interessante uma ligeira apreciação sobre seu conteủo foliar.

Seus teores foliares em si, nada têma ver com os diferentes tratamentos aplicados, uma vez que suas quantidades aplicadas aos solos foram fixas em todos os trata mentos correspondentes à formulação $\mathrm{N}-\mathrm{P}-\mathrm{K}$ igual a $30-20-60$. Não foi feita qualquer aplicação de $\mathrm{Mg}$, sendo que o seu teor encontrado nas folhas, revela a presença do mesmo, no solo, independente de qualquer aplicação. 
As curvas construídas permitem claramente vi sualizar e compreender que cada um destes quatro elementos (N, $P, K$ e $M g$ ) possui comportamento distinto, com relação à sua absorção e correspondente teor foliar, jä que os pontos de in flexão (cada ponto corresponde a um elemento) se adaptam per feitamente nas duas variedades, embora não coincidentemente.

Assim, o $N$ apresentou o maior teor foliar nas duas variedades, enquanto que o P mostrou o menor ( $t$ ambém pa ra as duas variedades). $0 \mathrm{~K}$ ocupou posição intermediäria (nas duas curvas), enquanto que o $\mathrm{Mg}$, embora não tenha sido aplica do ao solo, revelou teores foliares proximos entre si, nas duas variedades, numericamente um pouco acima do teor encon trado para o P.

5.4. Relação entre o teor dos elementos, encontrados nas folhas, e as respectivas produçöes médias obtidas

5.4.1. Teores foliares de Cálcio

A maior produção média por hectare (em ambas as variedades), foi observada nos tratamentos que receberam o gesso na dose relativamente alta, apiicado a lanço, em cobertura, logo após o plantio. Nestas plantas, o teor foliar de Cálcio foi relativamente major e numericamente igual nas duas variedades. 
A seguir, as produções mais elevadas (também paca ambas as variedades), corresponderam aos tratamentos on de o gesso foi aplicado na forma de mistura (doses também, relativamente altas). Nestes tratamentos, entretanto, os teo res foliares de Cálcio encontrados nas duas variedades foram discrepantes, relativamente maiores na variedade NA-5679 e infe riores na $C B-4176$. Esta diferença se deve, possivelmente, à influência varietal.

Fato interessante, já mencionado anteriormen te, foi que o teor foliar mais elevado de cálcio (na varieda de NA-5679), foi encontrado justamente no tratamento que rece beu somente enxofre elementar (em dose relativamente alta, 300 kg/ha em cobertura após o plantio). A respectiva produção ob tida, entretanto, situou-se um tanto aquém da maior produção observada (considerada também como boa, entretanto, sob o pon to de vista agronômico). Foi encontrado teor foliar de Cálcio igualmente elevado (ainda nesta variedade), no tratamento cu ja fonte de $\mathrm{N}$ foi o sulfato de amônio, e o gesso usado como mistura (dose relativamente elevada de gesso).

0 menor teor foliar de Cálcio, encontrado na variedade NA-5679 correspondeu a tratamento onde o gesso foi aplicado em pequena quantidade, no fundo do sulco de plantio. A produção obtida neste tratamento, entretanto, não foi das menores, sendo que pode ser, talvez, vantajoso economicamen. 
te, como jä foi dito antes, Na variedade $C B-4176$, näo obstar te este mesmo tratamento tenha resultado numa produção relati vamente menor, a mesma ainda è considerada satisfatória em termos agronômicos $(101,2 \mathrm{t} / \mathrm{ha}$, equivalente a 243 toneladas de cana-de-açūcar por alqueire), o que sugere a sua aplicação prática com bastanté bom resultado. Esta variedade mostrou te ores foliares de Cálcio relativamente maiores do que a outra, neste mesmo tratamento.

\subsubsection{Teores foliares de Enxofre}

Os teores foliares de enxofre em ambas as va riedades estudadas, situaram-se de modo geral, dentro de uma faixa de variação, compreendida entre 0,08 a $0,10 \%$ em respos ta à maioria dos tratamentos aplicados, não mostrando, portan to, relação definia entre teor foliar deste elemento e res pectiva produção, nesta fase de desenvolvimento da cultura.

Na variedade NA-5679, o teor foliar mais elevado de enxofre encontrado, correppondeu ao tratamento que não recebeu enxofre algum (testemunha), sendo entretanto, o tratamento que revelou a menor produção obtida. A outra va riedade estudada (CB-4176) mostrou comportamento diferente nes te sentido, com relação a este mesmo tratamento, que não obs tante tenha revelado a menor produção, seu respectivo taor fo liar de enxofre não foi o mais elevado. Nesta variedade (CB- 
.78.

4176), os maiores teores foliares de enxofre, corresponderam aos tratamentos onde o enxofre foi aplicado no sulco de plan tio (tanto na forma elementar, como contido no gesso), inde pendentemente das diferentes quantidades em que foi aplicado, não mostrando relação nítida, portanto, entre teores folia res deste elemento e respectivas produções obtidas, pelo me nos nesta fase de desenvolvimento da cultura.

A outra variedade (NA-5679) se comportou de

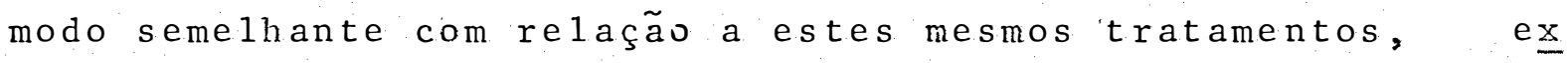
pressando entretanto, em relação à variedade CB-4176, teores foliares de Enxofre, numericamente inferiores. Também neste caso não se constatou qualquer relação definida entre teores foliares de enxofre e respectivas produções obtidas, nesta fa se do desenvolvimento da cultura.

o menor teor foliar de enxofre detectado foi apresentado pela variedade $\mathrm{NA}-5679$, correspondendo ao trata mento que não recebeu gesso nem enxofre elementar, tendo rece bido entretanto, uma quantidade relativamente inenor de enxo fre, contida no sulfato de amônio utilizado como fonte de $N$. A produção obtida neste caso, embora não tenha sido a menor, foi" muito aquém da máxima observada. 
6. CONCLUSÕES

6.1. Conclusões referentes à altura média das plantas

A altura média das plantas estä - biretamente relacionada com as quantidades de Cálcio e de Enxofre, oferecidas ao solo.

o gesso aplicado a lanço em cobertura após o

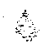
plantio, tarda um poucomais para manifestar o seu efeito so bxe a altura das plantas, do que quando apljcado no sulco de plantio, em quantidades semelhantes.

A supressão do Cälcio na adubação inibe o cres cimento das plantas em altura. 
A supressão simultânea de Cálcio e Enxofre na adubação, inibe com mais intensidade o crescimento das plantas em altura, do que quando se supre apenas um deles.

0 Enxofre elementar aplicado a lanço em cober tura após o plantio, em doses relativamente elevadas $(300 \mathrm{~kg} /$ ha), estimula, por si só (praticamente, sem cälíio) o crescímento das plantas de cana-de-açúcar em altura, pelo menos até certo limite, nesta fase do seu desenvolvimento.

Cálcio e Enxofre provenientes do gesso, quando aplicados em doses relativamente pequenas (50 kg gesso/ha) no sulco de plantio da cana-de-asucar, promovem conjuntamente o crescimento das plantas em altura, manifestando sob este a pecto, um efeito semelhante a observado quando o Enxofre ele mentar é fornecido isoladamente, porém em doses mais elevadas $(300 \mathrm{~kg} / \mathrm{ha})$.

Hâ influência varietal quanto à época Sidade de cultura) de manifestação de efeitos relativos à altura média das plantas, decorrentes da aplicaça de iguais tratamentos, manifestando efeitos que se correspondem, porém, em dife rentes idades.

6.2. Conclusöes referentes à produção média por hectare

o gesso aplicado a lanço em cobertura após o plantio, en quantidades relativamente elevadas (500 kg gesso/: 
ha) promove significativo aumento na produção de cana-de-açucar por unidade de área.

Produções relativamente elevadas de cana-de.. açũcar são obtidas (mesmo em solos arenosos), quando o gesso é empregado na forma de mistura com NPK na adubação de í plan tio (em dose relativamente alta, ao redor de $800 \mathrm{~kg}$ gesso/ha). A aplicação de doses relativamente menores de gesso (500 :kg/ ha) em cobertura apös o plantio promove, entretanto, copor = duções ainda majores.

A produção da cana-de-açücar é sensivelmente diminuida pela falta de Cálcio e de Enxofre na adubação.

O Enxofre elementar aplicado a lanço em cober tura após o plantio, em doses relativamente elevadas (300 kg/ ha), estimula por si só (praticamente sem cälcio) o aumento da produção média dé cana-de-açúcar por unidade de área, pelo menos até certo ponto, a partir do qual, somente a adubação completa é capaz de fazer atingir a produção máxima.

Dosses minima de Enxofre estimulam, por pouco que seja, o aumento da produção da cana-de-açúcar, o mesmo se dadndo com o cálcio.

Cá]cio e Enxofre provenientes do gesso, quando aplicados em doses relativamente pequenas (50 kg. gesso/ha) no sulco de plantio da cana-de-açicar, promovem conjuntamente o aumento da produção, atè níveis considerados ...sátísfátörios sob o aspecto econômicio. 
6.3. Conclusões referentes aos teores foliares dos elemen tos, em função das quantidades em que foram aplicados ao solo.

Hả influência varietal sobre o teor de Cảlcio e/ou Enxofre encontrado nas folhas de cana-de-açúcar, em de terminada fase do seu desenvolvimento, em função das quantida des em que são aplicados ao solo, juntos ou .... separadamente. Deste modo, considerando-se plantas de mesma idade, porém, de variedades diferentes, os teores foliares de cälcioe/ou de Enxofre, embora resultantes de iguais tratamentos, nem sempre serão equivalentes ou sequer semelhantes.

De modo geral, existe uma proporção direta en tre as quantidades de cálcio e de Enxofre, aplicados juntos (como gesso) ou separadamente ao solo, e o teor destes mesmos elementos encontrado nas folhas da cana-de-açúcar.

As folhas da cana-de-açūcar, parecem reter com maior intensidade em seus tecidos, justamente o elemento que se encontra com maior carência no solo, havendo diferen cas de comportamento varietal neste sentido, entretanto (considerando-se plantas de mesma idade), conforme a maior ou menor precocidade de cada variedade.

o fornecimento de doses mínimas do elemento que se encontra em maior carência no solo, faz com que o teor 
foliar deste mesmo elemento diminua sensivelmente, indicando possivelmenté a não necessidade de reserva do mesmo, em seus tecidos.

Os teores foliares de $N, P, K$ e $M g$, na cana-deaçūcar obedecem a um padrão uniforme em ambas as variedades estudadas, correspondendo-se de forma equivalente. Estes es tão diretamente relacionados com suas respectivas solubilidades no solo, existindo assim uma proporça direta entre solubilidade de cada um e o seu respectivo teor encontrado nas folhas.

6.4. Conclusães referentes aos teores foliares de Cälcio e de Enxofre e as respectivas produçōes mëdias por hectare.

Hâ uma relação direta entre o teor foliar de cálcio e a respectiva produção mảrima da cana-de-açúcar, em determinada fase de seu desenvolvimento, quando o gesso é aplicado a lanço em cobertura após o plantio, em doses relati. vamente elevadas ( $500 \mathrm{~kg} / \mathrm{ha})$. 
o teor foliar mais elevado de um determinado elemento (caso, o cálcio) na cultura de cana-de-açúcar em determinada fase de seu desenvolvimento, não corresponde ne cessariamente à maior produça obtida, havendo neste sentido diferencas de comportamento varietal.

A rigor, não existe una correlação direta en tre produção média obtida de cana-de-açúcar e respectivo teor foliar de câlcio, considerando-se determinada época de amostra gem.

As maiores produções médias obtidas na canade-acucar, em variedades diferentes submetidas a iguais tratamentos, não expressam necessariamente teores foliares de Cäl cio equivalentes, ou mesmo proximos entre si.

Diferentes variedades de cana-de-açücar podem responder de modo similar em relaça aos seus teores foliares de enxofre, proveniente de diferentes fontes, quantidades e formas em que è aplicado ao solo, não havendo porëm, qualquer relação definida entre os teores foljares deste elemento e respectivas produções médias, pelo menos nesta fase de desenvolvimento da cultura. 
ALVAREZ, R., F.C. VERDADE e H. OLIVEIRA, 1963. Fracionamento da dose de $N$ na cultura da cana-de-açúcar. Bragantia. Cam pinas. 22: $51-54$

ANDREIS, H.J., 1975. Macro and micro nutrient content of Millable Florida sugar cane. Sugar-Journal. New Orleans. $37: 10-12$.

ANônImo, 1969. Cane needs sulfur in its diet. Producers Rev., 59, (1), 49. Apud Internationa1 Sugar Journa1, 1970, 72:16. England.

ASSOCIAÇÃO NACIONAL PARA DIFUSÃo DE ADUBOS, 1975. Manual de Adubação. São Paulo. Editora "Ave Maria" Ltda. 346 p. 
.86.

BRASIL. Ministério da Agricultura. Serviço Nacional de Pesqui sas Agronômicas. Comissão de Solos, 1960. Levantamento de reconhecimento dos solos do Estado de São Pauto. Rio de Janeiro.634p. (Boletim no 12).

CASTILLA, A.C., 1954. Correcion de la alcalinidad de um suelo del valle, con aplicaciones de azufre, meso y lixiviacion. Estüdio en el invernadero. Acta Agronomica. Colombia. 4: 114.

CATANI, R.A. e A.O. JACINTHO, 1974. Avaliagão da fertilidade do solo-métodos de análise. São Paulo. Editora "Ave Maria" Ltda. $61 \mathrm{p}$

DEMATte, J.L.I. (S.d.). Curso de Gênese e Classificagão de so 2os. Piracicaba. Depto. Editorial do Centro Acadêmiso "Luiz de Queiroz". $348 \mathrm{p}$.

FERNANDES, A.J., 1984. Manual da Cana-de-Aqúcar. Piracicaba. Livroceres Ltda. $196 \mathrm{p}$.

FERNANDES, F.A., 1982. Gesso, Aplicasão na Agricultura. Semi närios de Solos e Nutrição de Plantas - E.S.A.L.Q. USP. Pira cicaba. (s.ed.). 28 p. 
FERREIRA, M.E., D. FORNASIERT, G.C.VITTI e C.MARVULO (S.d.). Estudos de doses e época de aplicação do gesso na cultura do amendoim, (Arachis hypogeal. Revista Cientifica. São Pau $10 . \quad($ no pre1o)

GALLO, J.R., R. HIROCE e R. ALVAREZ, 1968. Levantamento do es tado nutricional de canaviais de São Paulo, pela anälise foliar. Bragantia. Campinas. 27(30):365-382.

GOSNELL, J.M. e A.C. LONG, 1969. A sulfur deficiency in sugar cane. Proceedings 43 rd. Congress South African Sugar Technology Association: 26-29. Apud International Sugar Journa1, 1971, 73:80. England.

HAAG, H.P. e J. ORLANDO FILHO, 1976. Influência varietal e do solo no estado nutricional da cana-de-açüar ISaccharum sppl, pela anālise foliar. Anais da Escola Superior de Agri cultura "Luiz de Queiroz". Piracicaba. 33:105-147.

HERNANDO, V., M.P. SANCHEZ CONDE e J.G. CONTRERAS, 1963 . In fluência de los niveles de yeso y de humedad en la fertili dad de um suelo gesoso. Anales de Edafologia y Agrobiologia. Madrid. 22:323-337.

HOWES, F.N., 1967. Sugar cane research in Queensland. The International Sugar-Journal. England. 
.88.

HUMBERT, R.P., 1968. The nutrition of sugar cane. Cap. IV.

In: The Growing of Sugar Cane. Elsevier Publishing Company. Amsterdan. 223-224.

JONES, M.B. e J.E. RUCKMAN, 1966 . Gypsum and Elemental sulfur as fertilizers on annual grassland. Agronomy Journal. Madison. $58: 409-412$.

JONES, M.B. e J.E. RUCKMAN, 1969 . Effect of particle size on long-term availability of sulfur on annual-type grasslands. Agronomy Journal. Madison. 61:936-939.

KIEHL, E.J., 1979. Manual de Edafologia. São Paulo. Editora Agronômica "Ceres" Ltda. 262 p.

LEMOS, R.C. DE e R.D. DOS SANTOS, 1976. Manual de Mëtodo de Trabalho de Campo. Campinas. Sociedade Brasileira de Ciên cia do Solo. $36 \mathrm{p}$.

LIMA FILHo, S.A., 1977. Métodos de Anălises de Solos. Bandei rantes. Editado pela Fundação Faculdade de Agronomia Luiz Meneghe1. $81 \mathrm{p}$.

MAlavolta, E., 1976. Manual de Química Agricola-Adubos e Aḋubą̃ão. São Paulo, Editora Agronômica Ceres Ltda. 528p. 
.89.

MALAVOLTA, E., H.P. HAAG, F.A.F. MELLO e M.O.C. DO BRASIL SO BRINHo, 1976. Nutrigão Mineral e Adubagão de Plantas Culti vadas. São Pau1o, Livraria Pioneira Editora. $727 \mathrm{p}$.

MALAVOLTA, E., J.P. ROMERO, T.H. LIEM e G.C.VITTI, 1979. Ges so Agrícola, seu Uso na Adubagão e Corregão do solo. Pira cicaba. Depto. de Serviços Técnicos Agronômicos. Beletim Ultra Fértil. $32 \mathrm{p}$.

MALAVOLTA, E., V.F. CRUZ e L.G. SILVA, 1972. Foliar diagnosis in sugar cane V. Extension of the physiological economical concept of critical leve1. Anais da Academia Brasileira de Ciências. Rio de Janeiro. 44(2):349-353.

MAY, P.F., A.R. TILL e A.M. DOWNES, 1967. Nutrient cyc1ing in grazed pastures, 1 . A preliminary investigation of the use of ${ }^{35} \mathrm{~s}$ gypsum. Australian Journal of Agricultural Research, 1968. Austra1ian. 19-11:531-543.

MELLO, F.A.F., M.O.C. DO BRASIL SOBRINHO, S. ARZOLLA, A. C BRA NETTO e R.I. SILVEIRA, 1974. Fertilidade do Solo. Pira cicaba, Depto. Editorial do Centro Acadêmico "Luiz de Que roz". $197 \mathrm{p}$.

MONIZ, A.C. Cood., 1975. Elementos de Pedologia. Rio de Jane ro. Livoros Técnicos e Científicos Editora S/A. 45 9p. 
MUNSELL SOIL COLOR CHARTS, 1975. Munselz Soil Color charts. Baltimore, Maryland. MacBeth Division of Kollmorgen Corporation $17 p$.

ORLANDO FILHO, J., 1978. Absorção dos nutrientes pela canade-açūcar (Saccharum spp) variedade $C B$ 41-76 em três gran des grupos de solos no Estado de são Paulo. Piracicaba, ESALQ/USP, 76p. (Tese de Doutoramento).

ORLANDO FILHO, J. e H. DE CAMPOS, 1975. Nümero ideal de fothas para a diagnose foliar em cana-de-açūcar (Soqueira). - Brasil Agucareiro. Rio de Janeiro. 85(4):23-29.

PIMENTEL GOMES, F., 1973. Curso de Estatistica Experimental. (5 a ed.). Piracicaba. Livraria Nobe1 S.A. Editora-Distri buidora. 430 p.

PONTE A.M. DA, N.E. ARANTES; P.G. GUIMARÃES, M.B. DE PAULA e R.A. DE SOUZA, 1978 . Influência do gesso na fertilidade dos solos de cerrado para duas cultivares de soja lGlycinemax. (L) Merril) Interação entre níveis de calagem, níveis de gessagem e cultivares (Estudo Preliminar). Informe Agrope cuário. Belo Horizonte. (no prelo). 
POONIA, S.R. e D.R. BHUMBLA, 1972. Effect of esp on the availability of $\mathrm{Ca}$ from soil and added gypsum to maize (Zea mays) and dhaincha (Sesbania acuelata). Plant and Soit. The Hague. 36:671-679.

REEVE, N.G. e M.E. SUMNER, 1972. Amelioration of subsoil acidity in Natal oxisols by leaching of surface-applied amendments. Agrochemophysica. Pretoria, South Afric. 4:1-6.

SÃO PAULO. Secretaria da Agricultura. Acordo Instituto de Zootecnia/ultrafértil, 1977. Relatório no 1 do projeto sobre a utiliząão do gesso e da associąão fosfato natural+ges so em plantas forrageiras. Campinas. $46 \mathrm{p}$.

S̃̃o PAULO. Secretaria da Agricultura. Instituto Agronômico de Campinas, 1977. Tabelas de Adubacão e Calagem. Campinas. 196p. (Boletim no 209).

SEDL, J.M., 1968. The sulfur nutrition of sugar cane. Proceedings 35 th. Conf. Queensland Society Sugar Cane Technology: 131-135. Apud International Sugar Journal,

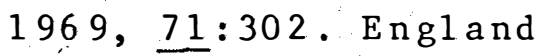

SILVEIRA, R.I., F.A.F. DE MELLO, M.O.C. DO BRASIL SOBRINHO e S. ARZOLla, 1978. Adubos e Adubacão das Principais Culturas Brasileiras. Piracicaba, Depto. Editorial do Centro Acadêmico "Luiz de Queiroz". 223 p. 
TAKKAR, P.N. e T. SINGH, 1978. Zinc nutrition of rice as influenced by rates of gypsum and $\mathrm{Zn}$ fertilization of alkali soils. Agronomy Journal. Madison. 70:447-450.

TEIXEIRA, N.T., 1980. Comportamento do nitrogênio "solúvel" em cana soca, em condições de campo e em variedades de cana-de-açücar cultivas em solução nutritiva. Piracicaba, ESALQ/USP, 83P. (Tese de Doutoramento).

WANG, C.H., T.H. LIEM e D.S. MIKKELSEN, 1976 a. Sulfur deficiency a limiting factor in rice production in the lower Amazon - Basin I. Development of sulfur deficiency as a limiting factor for rice production. IRI. Manila. 47:16-23.

ZAMBELLO, JR., E. H.P. HAAG e J. ORLANDO FILHO, 1981. Influên cia da época de amostragem foliar e do tipo de solo na diagnose foliar de soqueira da cana-de-açūcar. Saccharum. São Pau 1o. $3: 23-30$. 